Antimicrobial potential of bioactive metabolites, Silver nanoparticle from Bacillus spp.

and some antibiotics against Multidrug Resistant Salmonella spp.

Bukola Christianah Adebayo-Tayo, Oluwadara Ekundayo-Obaba and Olutayo Israel Falodun

Department of Microbiology, University of Ibadan, Ibadan, Oyo State, Nigeria.

\title{
Email: bukola.tayo@gmail.com
}

Telephone +234 8035522409

Running Title: Antagonistic potential of metabolite and nanoparticles from Bacillus sp.

\section{ABSTRACT}

Objective: The synthesis of nanoparticles using microorganism and their metabolites are of increasing interest because they are potential producer of biocompatible and environmental friendly nanoparticles. Their nanoparticles can serve as potent alternatives to antibiotics against multidrug resistance bacteria (MDR). Antibacterial potential of Bacillus spp. metabolite, its silver nanoparticles and some antibiotics against multi drug resistant Salmonella spp. was evaluated.

Method: The antimicrobial potential of metabolites from Bacillus spp. was determined and SNPs biosynthesized using the metabolites was characterized. The effect of physicochemical parameters on SNPs biosynthesis, antimicrobial activity of the SNPs and combination of SNPs and antibiotics against Multidrug Resistant (MDR) Salmonella strains were evaluated.

Result: The bioactive metabolites of the Bacillus spp. exhibited varied antimicrobial potential against the tested MDR Salmonella spp. The metabolites were able to bioreduced $\mathrm{AgNO}_{3}$ to $\mathrm{Ag}^{0}$ for SNPs biosynthesis. Change in colour from whitish to darkish brown and Surface Plasma Resonance (SPR) peak of 600 - $800 \mathrm{~nm}$ was observed. The SNPs were aggregated, rods and crystalline in shape and the sizes were $15 \mu \mathrm{m}, 16$ $\mu \mathrm{m}$ and $13 \mu \mathrm{m}$. Carboxylic acid, amino acid, alcohol, esters and aldehydes were the functional group found in the biosynthesized SNPs. The antibacterial activity of BAC1SNPs, BAC7-SNPs and BAC20-SNPs against the MDRSA9 and MDRSA18 ranged 
50 from $6.0-22 \mathrm{~mm}$ and $11-20 \mathrm{~mm}$. SNPs biosynthesized at $\mathrm{pH} 7$ and 10mM AgNO3

51 had the highest antagonistic activity. Combination of SNPs and antibiotics exhibited the 52 best antagonistic potential. 
Conclusion: The metabolites and SNPs biosynthesized using Bacillus spp. Metabolites

exhibited antagonistic effect against MDR Salmonella spp. The combined SNPs and antibiotics had better antimicrobial activity.

Keywords: Bacillus strains, metabolites, Antimicrobial, Silver nanoparticles, MDR

Salmonella species, Synergistic effect.

TURKISH ABSTACT

Amaç: Mikroorganizma ve bunların metabolitlerini kullanan nanopartiküllerin sentezi, biyolojik olarak uyumlu ve çevre dostu nanopartiküllerin potansiyel üreticisi olmaları nedeniyle artan ilgi konusudur. Onların nanopartikülleri, çoklu ilaç dirençli bakterilere (MDR) karşı antibiyotiklere güçlü alternatifler olarak hizmet edebilir. Bacillus spp.'nin antibakteriyel potansiyeli metabolit, gümüş nanoparçacıkları ve çok ilaca dirençli Salmonella spp. Değerlendirildi. Yöntem: Bacillus spp.'den metabolitlerin antimikrobiyal potansiyeli. belirlendi ve metabolitler kullanılarak biyosentezlenen SNP'ler tanımlandı. Fizikokimyasal parametrelerin SNP biyosentezi, SNP'lerin antimikrobiyal aktivitesi ve SNP'lerin ve Çoklu İlaç Dirençli (MDR) Salmonella suşlarına karşı antibiyotik kombinasyonu üzerindeki etkisi değerlendirildi.

Sonuç: Bacillus spp. Nın biyoaktif metabolitleri. Test edilen MDR Salmonella spp'ye karşı çeşitli antimikrobiyal potansiyel sergiledi. Metabolitler, SNP biyosentezi için AgN03'ü Ag0'a indirgenebildi. Rengi beyazımsı ila kahverengimsi kahverengiye dönüşmüş ve 600 - 800 nm Yüzey Plazma Rezonansı (SPR) zirvesi gözlenmiştir. SNP'ler toplandı, çubuklar ve kristal şeklinde ve boyutları 15 um, 16 um ve 13 um idi. Karboksilik asit, amino asit, alkol, esterler ve aldehitler, biyosentezlenmiş SNP'lerde bulunan fonksiyonel gruptu. BAC1-SNP'lerin, BAC7-SNP'lerin ve BAC20-SNP'lerin MDRSA9 ve MDRSA18'e karşı antibakteriyel aktivitesi 6,0 - $22 \mathrm{~mm}$ ve $11-20 \mathrm{~mm}$ arasında değişmiştir. PH 7 ve $10 \mathrm{mM}$ AgN03'te biyosentezlenen SNP'ler en yüksek antagonistik aktiviteye sahipti. SNP'lerin ve antibiyotiklerin kombinasyonu en iyi antagonistik potansiyeli göstermiştir.

82 Sonuç: Metabolitler ve SNP'ler Bacillus spp. Kullanılarak biyosentezlenmiştir. 83 Metabolitler, MDR Salmonella spp.'ye karşı antagonistik etki göstermiştir. Kombine SNP'ler ve antibiyotikler daha iyi antimikrobiyal aktiviteye sahipti.

\section{5}

\section{Introduction}

87 Infections caused by harmful microorganisms affect many people globally and it's an 88 important cause of morbidity and mortality with adverse effect on the healthcare 89 economy ${ }^{1,2}$. The treatment of these infections has become a public health concern as a result of development of resistance to antibiotics by these etiological agents ${ }^{3,4}$. 
91 Salmonella, the most commonly isolated food borne pathogens associated with fresh

92 fruits and vegetables, is a gram negative flagellated rod-shaped facultative anaerobe bacterium 5,6 . Salmonella is a group of bacteria that causes typhoid fever, food poisoning, gastroenteritis, enteric fever and other illnesses. Salmonella infections or Salmonellosis, are bacterial diseases of the intestinal tract.

The occurrence of enteric fever has been a major health problem in spite of the use of antibiotics and the development of newer antimicrobials. Resistance of Salmonella spp. to previously efficacious drugs like ciprofloxacin, ampicillin, ceftriaxone, and cotrimoxazole has been reported ${ }^{7}$. Adabara et al. ${ }^{8}$ reported the prevalence and antibiotic susceptibility pattern of Salmonella typhi among patients attending a military hospital in Minna, Nigeria. The isolates were resistant to all of the antibiotics tested which are the drug of choice routinely used in the study area for the treatment of typhoid 104 fever.

MDR Salmonella strains are very common and are the causative agent of endemic and epidemic typhoid fever infections in many communities. MDR Salmonella typhi poses a serious threat because they have developed resistance to available antibiotics resulting in an increase in death rate and high capability for epidemic outbreaks of typhoid which

111 The consequence of typhoid fever outbreak may be highly destructive most especially in 112 developing countries where health facilities are very poor. Salmonella has been 113 reported as the most common cause of bacterial food-borne illness in the U.S. and is 114 estimated to annually cause over 1 million cases, 19,000 hospitalizations, 350 deaths, 115 and $\$ 2.6$ billion in social costs 9,10 . Salmonella enterica serovar typhimurium is one of 116 the most common salmonellae in humans and livestock, and most of these strains are 117 resistant to multiple antibiotics.

Bacillus species are Gram-positive, endospore-forming, chemoheterotrophic rodshaped bacteria which are usually motile with peritrichous flagella; they are aerobic or facultative anaerobic and catalase positive and a member of the phylum Firmicutes. 
Many Bacillus species are of remarkable importance because they are antibiotics producer. B. subtilis, B. polymyxa, B. brevis, B. licheniformis, B. circulans, B. cereus has been reported as an antibiotics producers. Antibiotics such as bacitracin, gramycidin S, polymyxin and tyrotricidin produced by Bacillus spp. have found application in medical treatments ${ }^{11-14}$. The wide range of antimicrobial, anti-viral, antiameobocytic and anti-mycoplasma activities of Bacillus species have been reported 1517 .

The ability of Bacillus species to produce different metabolites with antimicrobial activity has been extensively used in medicine and pharmaceutical industry; one of its potential is on its application as a bio-control agent for animals, humans and plants diseases ${ }^{18}$.

Silver and silver containing products are one of the most popular and efficient antimicrobiocidal agents commonly used against pathogenic bacteria ${ }^{19}$. Since the ancient times silver has been in used as an antimicrobial agent but with the development of antibiotics, there has been a reduction in the medical applications of silver as an antimicrobial ${ }^{20}$.

Nano level manipulation and physicochemical changes of silver can lead to production of silver nanoparticles with an increase in antimicrobial potential. Silver nanoparticles are characterized with high surface-area-to-volume ratio and the unique chemical and physical properties which confer on them better antimicrobial properties ${ }^{21}$.

Silver nanoparticles having size in the range of 10-100 nm showed strong bactericidal potential against both Gram-positive and Gram-negative bacteria ${ }^{22}$. Silver in the form of SNRs is known to exhibit strong biocidal effects on different bacterial strains, including multidrug resistant bacteria ${ }^{23,24}$. SNPs have little chance of drug resistance which provides a solution to multidrug resistance problems ${ }^{25}$. Drug resistance has been reported as one of the most serious threatening and widespread problems in all the developing countries ${ }^{26}$. Hence, diverse medical applications of AgNPs is necessary to avoid the effect of these drug-resistant pathogenic microorganisms by various methods, ranging from silver-based dressings and silver-coated medical devices such as 
152 nanogels and nanolotions, to dental materials, sunscreen lotions, and water treatment,

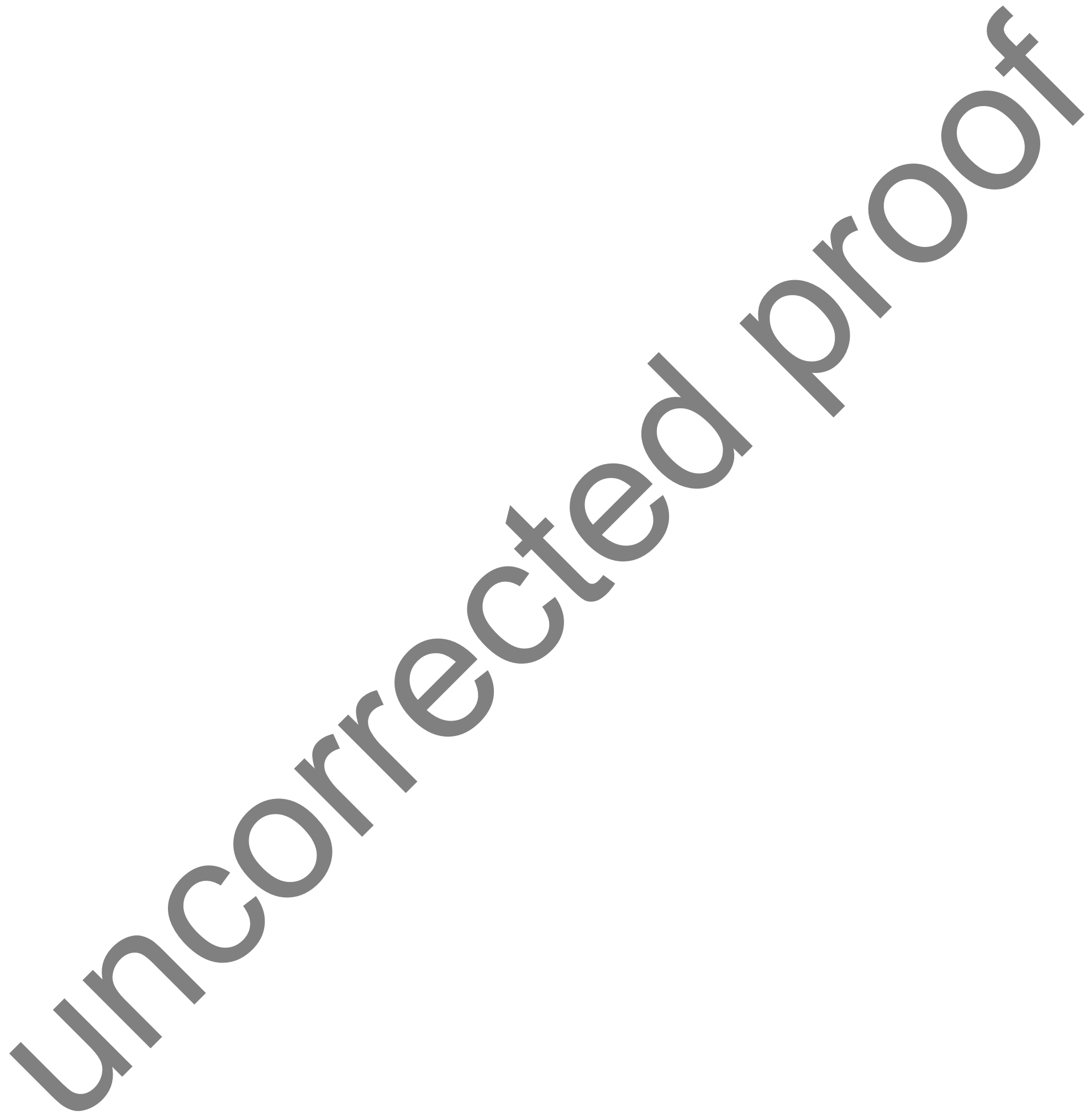


biological labelling, water treatment, in optical devices and as antibactericidal ${ }^{27-29}$. Microbial resistance to antimicrobials is highly prevalent worldwide, particularly in developing countries and this has made therapeutic options to appear more limited than ever. As a result of the emergence of MDR pathogen research interest has been geared towards the development of efficient and safe antimicrobials. For these reasons, this research aimed at investigating the antimicrobial potential of metabolites from Bacillus spp., its SNPs and combination of the SNPs with some antibiotics against some selected MDR Salmonella spp.

\section{Materials and Methods}

\section{Microorganisms}

Culture of Bacillus spp. previously isolated from fermented locust bean (Parkia biglobosa) samples and 10 MDR Salmonella spp. was obtained from the culture collection of our previous work in Microbial Physiology and Biotechnology Unit, Department of Microbiology, University of Ibadan. The isolates was kept on Nutrient agar slants and kept in the refrigerator. Constant sub culturing was carried out to ensure the viability of the isolates.

\section{Production of bioactive metabolites from Bacillus strains}

Three Bacillus strains were used for the production of bioactive metabolites using sterile Nutrient broth (NB). The sterile NB was inoculated with the young culture of Bacillus sp. the inoculated broth was incubated at $35^{\circ} \mathrm{C}$ for $48 \mathrm{hrs}$. The supernatant obtained from the fermentation broth was used as bioactive metabolites.

\section{Antagonistic potential of the bioactive metabolites produced by Bacillus spp.} against some MDR Salmonella spp.

The antagonistic potential of the bioactive metabolites against some MDR Salmonella spp. was investigated using Agar well diffusion method ${ }^{30}$. The inoculum suspensions of $24 \mathrm{hr}$ old culture of the Salmonella spp. was spread plated on Mueller Hinton agar (MHA). Uniform wells of $6 \mathrm{~mm}$ were bored on the agar. Each well was filled with $60 \mu \mathrm{l}$ of 

The antibacterial activity of the biosynthesized SNPs and the synergistic effect of SNPs

the bioactive metabolites from the Bacillus isolates. The plates were incubated at $37^{\circ} \mathrm{C}$ for $24 \mathrm{hrs}$. The incubated plates were observed for a zone of inhibition (ZOI) around the well. Formation of a clear zone around the well is an indication of antibacterial activity ${ }^{31}$. Results were considered positive if the diameter $(\mathrm{mm})$ of the $\mathrm{ZOI}$ around the well was greater than $1 \mathrm{~mm}$. The bioactive metabolites of the best three Bacillus spp. were used for further studies.

\section{Production of SNPS using the selected Bacillus strains}

The bioactive metabolites the best three Bacillus spp. were used for the production of SNPs. $30 \mathrm{~mL}$ of the bioactive metabolites was added to $70 \mathrm{~mL}$ of $10 \mathrm{mM} \mathrm{AgNO}_{3}$ solution. The mixture was stored at room temperature $\left(35^{\circ} \mathrm{C}\right)$ in a dark place for $24-72$ hrs. After $12 \mathrm{hrs}$ incubation, the whitish solution turned brownish which confirmed the formation of SNPs.

\section{Characterization of the Synthesized SNPs}

The SNPs was characterized using Visual detection for change in colour, UV-Visible absorption spectra of the were analyzed at room temperature using UV-Vis spectrophotometer (a Lambda 25-Perkin Elmer, Waltham, MA, USA) with a resolution of $0.5 \mathrm{~nm}$ at the wavelengths of $200-800 \mathrm{~nm}$. The FTIR spectra of the nanoparticles were analyzed using FTIR spectroscopy (Shimadzu) operated at resolution of $4 \mathrm{~cm}-1$. The size, shape and morphology of the biosynthesized SNPs were determined using SEM.

Antibacterial activity of the SNPS against some selected (MDR) Salmonella spp. and their synergetic effect with some selected Antibiotic

along with some selected antibiotics (Ciprofloxacin, Zinnacef, Amoxicillin, Pocephin, Streptomycin, Ampliclox and Gentamycin) was tested using agar well diffusion method ${ }^{30}$ against the selected MDR Salmonella spp. as previously described. 
Minimum inhibitory concentration was carried out using different concentration (100\%,

$21050 \%, 25 \%, 12.5 \%, 6.25 \%$, and $3.125 \%$ ) of the SNPs against the isolates ${ }^{30}$. The lowest

211 dilution of the SNPs at which zones of inhibition was observed against the Salmonella

212 sp. is regarded as the MIC for each SNPs. Ciprofloxacin was used as positive control.

\section{Effect of physiochemical parameters on the SNPs biosynthesis}

214 The effect of temperature $\left(25^{\circ} \mathrm{C}, 35^{\circ} \mathrm{C}\right.$ and $\left.40^{\circ} \mathrm{C}\right), \mathrm{pH}(4,7$ and 9$)$ and different

215 concentration of $\mathrm{AgNO}_{3}(2-10 \mathrm{mM})$ on the biosynthesized SNPs was evaluated.

Results and Discussion

217 The antimicrobial activity of the bioactive metabolites of the Bacillus spp. against some 218 MDR Salmonella spp. is shown in Table 1. The antimicrobial activity of Bacillus subtilis 219 BAC1, B. licheniformis BAC7 and Bacillus subtilis BAC20 bioactive metabolites against 220 the 10 MDR Salmonella strains ranged from $3.0-17.0 \mathrm{~mm}, 4-14 \mathrm{~mm}$ and $14-2.0$

$221 \mathrm{~mm}$. MDRSA9 and MDRSA20 had the highest susceptibility.

222 Table 1: Antimicrobial activity $(\mathrm{mm})$ of the bioactive metabolites of Bacillus spp. against 223 some MDR Salmonella spp.

\begin{tabular}{|c|c|c|c|c|c|c|c|c|c|c|}
\hline oacti & $M \cap R$ & armor & stra & / Zor & e of inhi & ition $(n$ & & & & \\
\hline & & SA15 & $\begin{array}{l}\text { SA3 } \\
2\end{array}$ & SA20 & $\begin{array}{l}\text { SA32 } \\
b\end{array}$ & SA9 & SA7 & SA18 & SA21 & SA8 \\
\hline BSM & $7.0 \pm$ & $11.0 \pm$ & $8.0 \pm$ & $5.0 \pm 1$ & $4.0 \pm 1$ & $17.0 \pm$ & $4.0 \pm+$ & $10.0 \pm$ & $0.0 \pm 0$ & $3.0 \pm 0$ \\
\hline (BAC1) & $0.5^{\mathrm{e}}$ & $1.0^{\mathrm{b}}$ & $0.5^{d}$ & $.00^{f}$ & $.0^{\mathrm{fg}}$ & $0.5^{\mathrm{a}}$ & $1.0^{\mathrm{fg}}$ & $1.0^{c}$ & $.0^{\mathrm{h}}$ & $.5^{9}$ \\
\hline BLM & $0.0 \pm$ & $10.0 \pm$ & $6.0 \pm$ & $4.0 \pm 1$ & $10.0 \pm$ & $14.0 \pm$ & $0.0 \pm 0$ & $12.0 \pm$ & $10.0 \pm$ & $11.0 \pm$ \\
\hline (BAC7) & $0.0^{g}$ & $0.5^{d}$ & $0.5^{\mathrm{e}}$ & $.0^{f}$ & $0.0^{d}$ & $1.0^{\mathrm{a}}$ & $0^{9}$ & $0.5^{\mathrm{b}}$ & $0.0^{d}$ & $1.0^{c}$ \\
\hline $\begin{array}{l}\text { BMM } \\
\text { (BAC2 }\end{array}$ & $2.0 \pm$ & $0.0 \pm 0$ & $0.0 \pm$ & $14.0 \pm$ & $\begin{array}{l}12.0 \pm \\
0 .\end{array}$ & $\begin{array}{c}6.0 \pm 1 \\
e^{e}\end{array}$ & $\begin{array}{l}2.0 \pm 0 . \\
0^{f}\end{array}$ & $\begin{array}{l}11.0 \pm \\
d\end{array}$ & $6.0 \pm 0$ & $\begin{array}{l}13.0 \pm \\
5^{b}\end{array}$ \\
\hline 0) & & & $0.0^{9}$ & & & & & & & $0.5^{\mathrm{b}}$ \\
\hline
\end{tabular}


226 Values are Means \pm Standard Deviations of triplicate observations. Means with different 227 alphabets across the row respectively are statistically significant at $p \leq 0.05$.

228 The ability of the Bacillus spp. metabolites to inhibit the test pathogens may be as a 229 result of the production of some bioactive metabolites. Several antimicrobial activities of 230 Bacillus spp. against pathogens have being reported. Antagonistic activity of Bacillus 231 subtilis and Bacillus cereus against Staphylococcus spp. has been reported by Perez et 232 al. ${ }^{13}$ and Riley and Wertz ${ }^{32}$.

\section{Biosynthesis of SNPs using Bacilli spp. broth}

234 The 3 bioactive metabolites was able to bio-reduced the $\mathrm{AgNO}_{3}$ to produce SNPs by 235 the evident of change in colour from whitish reaction mixture to darkish-brown which 236 indicate the formation of SNPs.

237 The biosynthesis of silver nanoparticles was done using the bioactive metabolites of 238 Bacillus spp. with the highest antagonistic potential from the previous screening. This is 239 in accordance with the work of Kalishwaralall et al. ${ }^{33}$ who biosynthesized SNPs from 240 culture supernatant of Bacillus licheniformis. The culture supernatant was able to 241 bioreduced $\mathrm{Ag}^{+}$to $\mathrm{Ag}^{\circ}$. Kanmani and $\mathrm{Lim}^{34}$ reported the bioreduction of $\mathrm{Ag}^{+}$to $\mathrm{Ag}^{\circ}$ 242 using exopolysaccharides.

243 Changes in colour from white to brown indicate SNPs biosynthesis. A visible colour 244 change from whitish yellow to brown was also reported by El-Batal et al., ${ }^{35}$. Changes in 245 colour may be attributed to the Surface Plasmon Resonance ${ }^{34}$.

\section{SPECTROPHOTOMETRIC ANALYSIS OF THE BIOSYNTHESIZED SNPS}

248 The biosynthesized SNPs were characterized with UV-Visible spectroscopy. The UVabsorption measurements in the range of $200-1000 \mathrm{~nm}$ was observed (Figure $1 \mathrm{a}-\mathrm{c}$ ).

250 The UV - spectra of the biosynthesized SNPs using BAC1 metabolite incubated at 24, 48 and $72 \mathrm{hrs}$ had the highest Surface Resonance Peak (SPR) at $600 \mathrm{~nm}$ (Figure 1c). SNPs from BAC7 metabolite had the highest SPR peak at $800 \mathrm{~nm}, 600 \mathrm{~nm}$ and 
$254 \mathrm{~nm}, 600 \mathrm{~nm}$ and $800 \mathrm{~nm}$ at 24, 48 and $72 \mathrm{hrs}$ of incubation (Figure 1c) which 255 corresponds to plasmon excitation of the SNPs. All the peaks obtained were in the 256 range of $400-800 \mathrm{~nm}$. There was variation in SPR peak of the SNPs incubated at 257 different time interval.
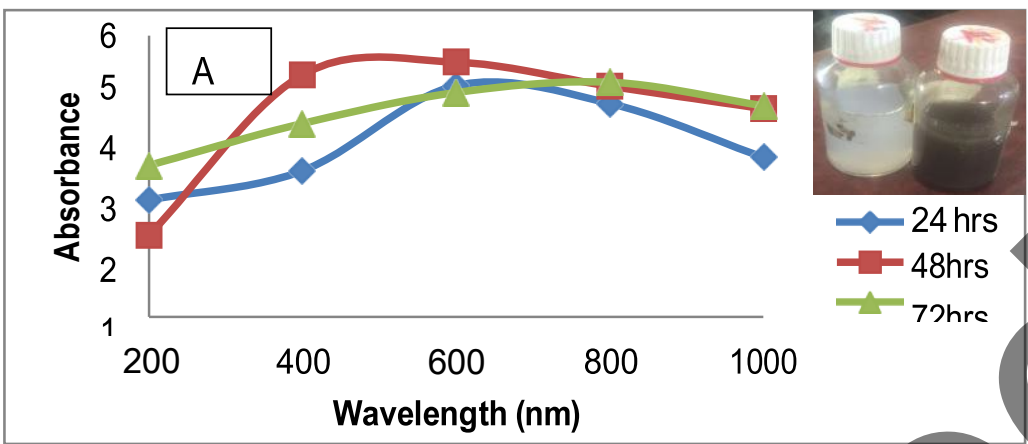

260

261
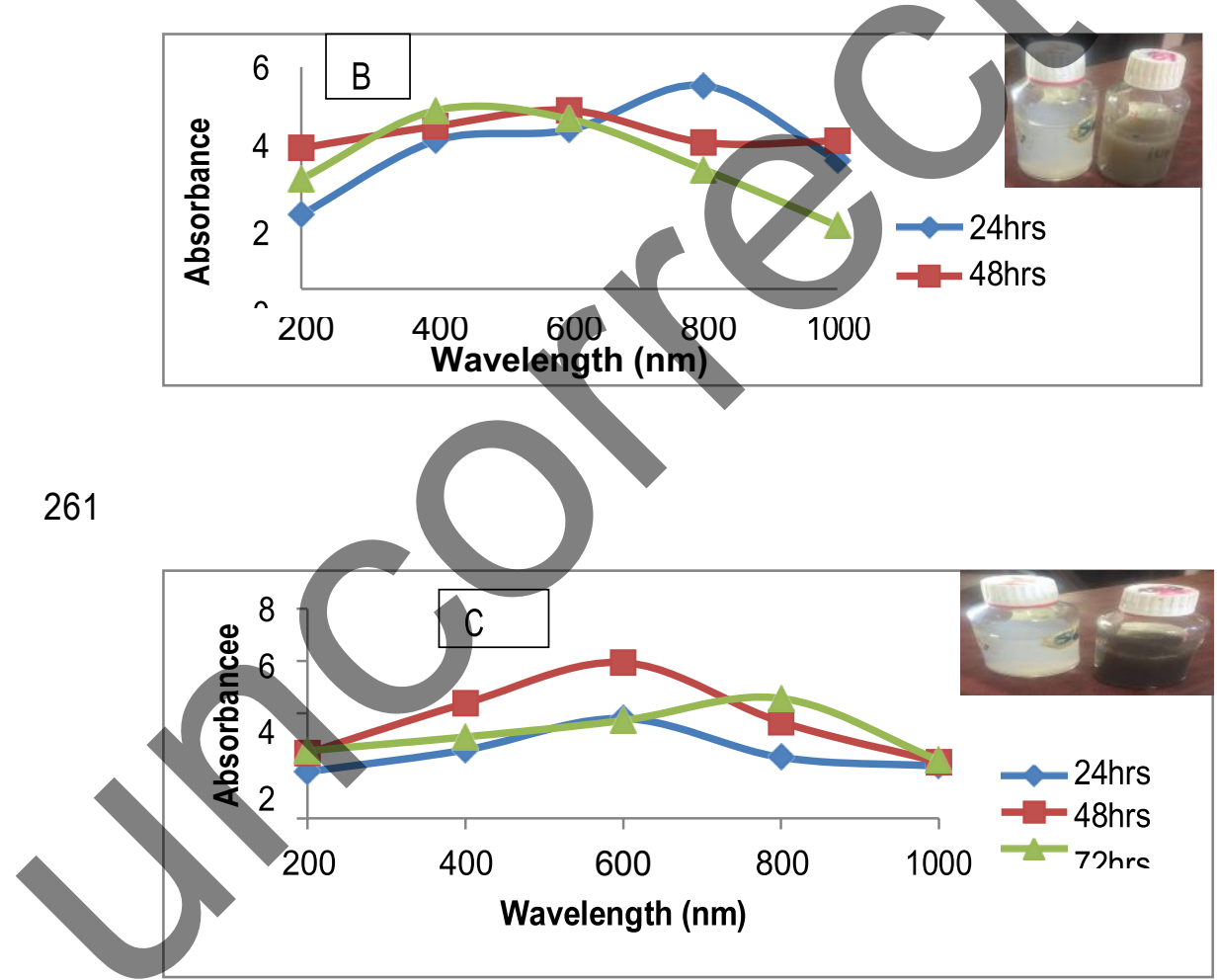

264 Figure $1 \mathrm{a}-\mathrm{c}$ : UV-Visible spectra of the SNPs biosynthesized using metabolites of 
265 Bacillus spp. (A) BAC1-SNPs, (B) BAC7- SNPs and (C) BAC20-SNPs at different 266 incubation time

267 
268 Primary confirmation of the silver nanoparticle biosynthesis was carried out by UV269 visible spectroscopy in the range of $200-1000 \mathrm{~nm}$. A strong SPR peak was observed at $270600 \mathrm{~nm}$ for the SNPs biosynthesized by the Bacillus subtilis BAC1 and BAC20 after 24 271 hrs of incubation indicates the formation of SNPs that varied in shapes and sizes. 272 Kanmani and Lim, ${ }^{34}$ reported a strong SPR peak at $400-550 \mathrm{~nm}$ with a broad band. El273 Batal et al. ${ }^{35}$ reported a SPR band at $431 \mathrm{~nm}$ of the SNPs synthesized with Bacilus 274 stearothermophilus indicating the presence of spherical or roughly spherical SNPs. 275 Valencia et al. ${ }^{36}$ reported that solutions containing SNPs developed a yellow colour 276 from initial whitish colour and presented SPR peaks between $411-414 \mathrm{~nm}$.

\section{Scanning Electron Microscopy}

279 The biosynthesized SNPs were characterized by SEM. Figure $2(a-c)$ shows the 280 micrographs of the SNPs. The SEM images shows SNPs from BAC1, BAC7 and 281 BAC20 were of varying shapes and sizes. BAC1-SNPs were aggregated, BAC7-SNPs 282 were aggregated rods and BAC20-SNPs were crystalline in shape (Figure $2 a-c$ ). 283 The sizes were $15 \mu \mathrm{m}, 13 \mu \mathrm{m}$ and $10 \mu \mathrm{m}$ respectively.

284
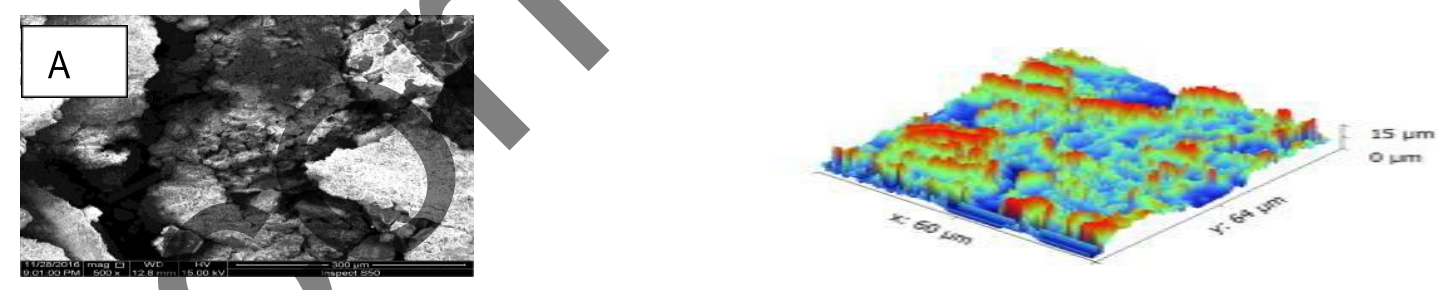

285
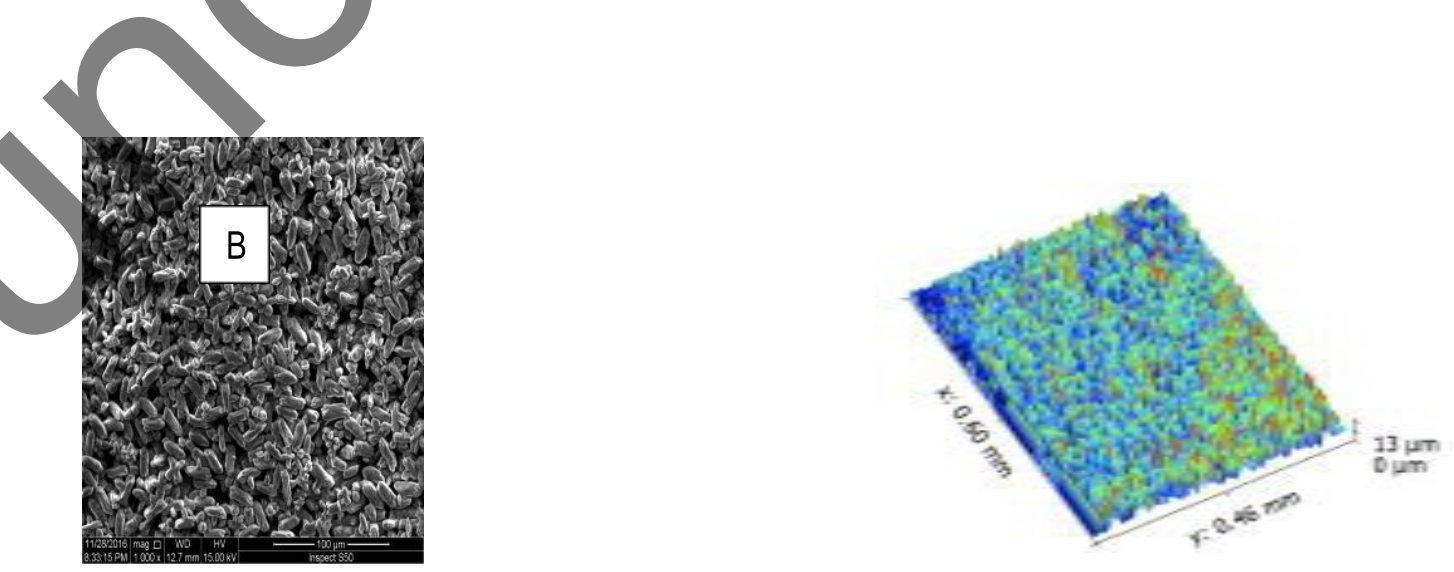

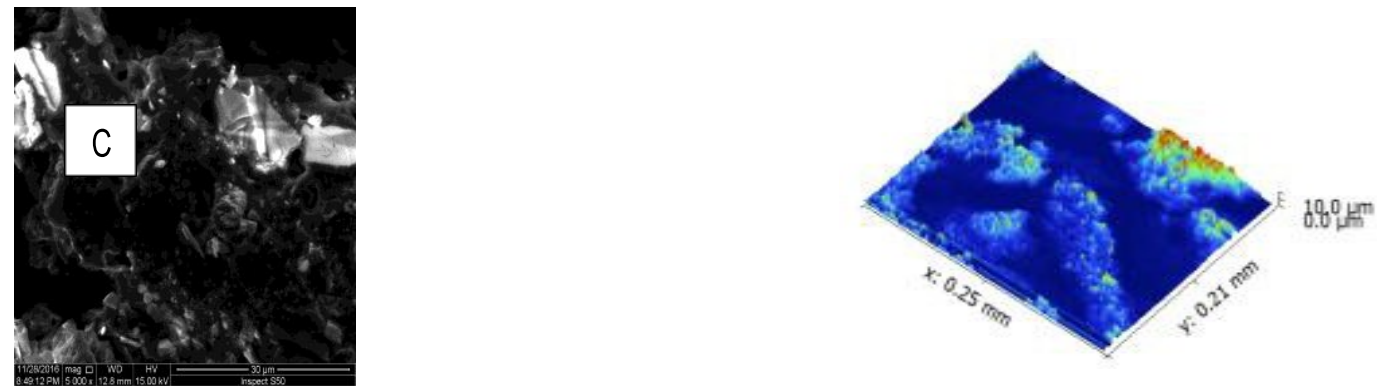

Figure 2c: SEM micrograph of SNPs biosynthesized using metabolites of Bacillus spp.

(A), BAC1-SNPs, (B) BAC7- SNPs and (C) BAC20-SNPs

291 Scanning electron microscopy (SEM) is used for the morphological characterization at 292 the nanometer to micrometer scale and can provide morphological information on the 293 submicron scale and elemental information at the micron scale as reported by Schaffer 294 et al. ${ }^{37}$.

295 SEM studies revealed that the biologically synthesized SNPs are different in size and 296 shape and they showed that they were aggregated, rod shaped and crystalline. The 297 aggregation observed may be due to the drying process. This observation agrees with 298 the work of Sadowski et al ${ }^{38}$ who observed aggregated SNPs biosynthesized using 299 Penicillium strains isolated from the soil. They concluded that the drying can affect the 300 shape and size of SNPs.

301 Rod shape observed in BAC7-SNPs is in accordance with the work of Gardea302 Torresday et al., 39 who reported rod shape from the SEM characterization of 303 biosynthesis of gold nanoparticles from Triticum aestivum leaves.

304 Crystalline SNPs observed in this work agrees with the report of Vithiya et al. ${ }^{40}$ who 305 reported that the shape of the extracellular biosynthesized SNPs from Bacillus spp. was 306 monodispersed.

\section{FTIR Spectra of the SNPs}

308 FTIR analysis of the SNPs was carried out to identify interactions between silver salts 309 and protein molecules, which could account for the reduction of silver ions and 310 stabilization of the SNPs formed. 
The BAC1-SNPs characterized using FTIR shows 7 bands with transmission peaks at $3448.00,2937.14,1638.92,1552.59,1404.40,1103.65$ and $607.24 \mathrm{~cm}^{-1}$ (Figure 3a).

313 The bands corresponded to $\mathrm{O}-\mathrm{H}$ stretch of alcohol, $\mathrm{C}-\mathrm{H}$ symmetrical stretch, presence 314 of amide, $\mathrm{NH}$ bend, $\mathrm{C}=\mathrm{O}$ stretch, $\mathrm{C}-\mathrm{O}$ stretch of alcohol and acetylenic $\mathrm{CH}$ of alkynes 315 respectively. The functional groups generally observed indicated the presence of amino 316 acids, alcohol, aldehydes and carboxylic acid in the sample and this may be responsible 317 for the reduction of silver nitrate to SNPs.

The FTIR analysis of BAC7-SNPs shows 9 bands and the peaks spectrum ranged from $3423.00 \mathrm{~cm}^{-1}$ and $352.84 \mathrm{~cm}^{-1}$ (Figure $3 \mathrm{~b}$ ). The peaks were attributed to $\mathrm{O}-\mathrm{H}$ stretch vibration of alcohol, symmetrical $\mathrm{C}-\mathrm{H}$. $\mathrm{C}=\mathrm{O}$ stretch of carboxylates and $\mathrm{NH}$ stretch of secondary amides, presence of $\mathrm{O}-\mathrm{H}$ bends of esters, phenol and tertiary alcohol or C-C bend of aldehyde, $\mathrm{C}-\mathrm{O}$ stretching vibration of carboxylic esters, C-O stretching vibration of secondary alcohol, presence of acetylenic $\mathrm{CH}$ of alkynes and aromatic benzene ring. From the FTIR spectrum, it was observed that the SNPs were surrounded by carboxylic acid, aldehyde, esters, protein and amino acids which may be responsible for the biosynthesis and stability of the SNPS (Figure 4b).

328 The FTIR analysis of BAC20-SNPS revealed 12 absorption peaks which ranged between $3760.00 \mathrm{~cm}^{-1}$ and $361.39 \mathrm{~cm}^{-1}$. The peak indicated the presence of an O-H 330 stretch free, strong alcohol, $\mathrm{O}-\mathrm{H}$ stretch vibration of alcohol, $\mathrm{C}-\mathrm{H}$ symmetrical stretching, 331 carbonyl stretching of transition metals, $\mathrm{NH}$ bend of amide, $\mathrm{NH}$ stretch of secondary 332 amides, $\mathrm{C}-\mathrm{O}$ stretch of esters, carboxylic acids, acetylenic $\mathrm{CH}$ of alkynes and weak 333 aromatic benzene. The functional groups corresponded to the FTIR spectrum generally 334 indicated the presence of amino acids, alcohol, aldehydes and carboxylic acid which 335 may be responsible for the reduction of silver nitrate to SNPs (Figure 3c). The presence of the intense pick at $\mathrm{C}=\mathrm{O}$ stretching mode indicates the presence of carboxylic groups 337 in the material bound to SNPs 

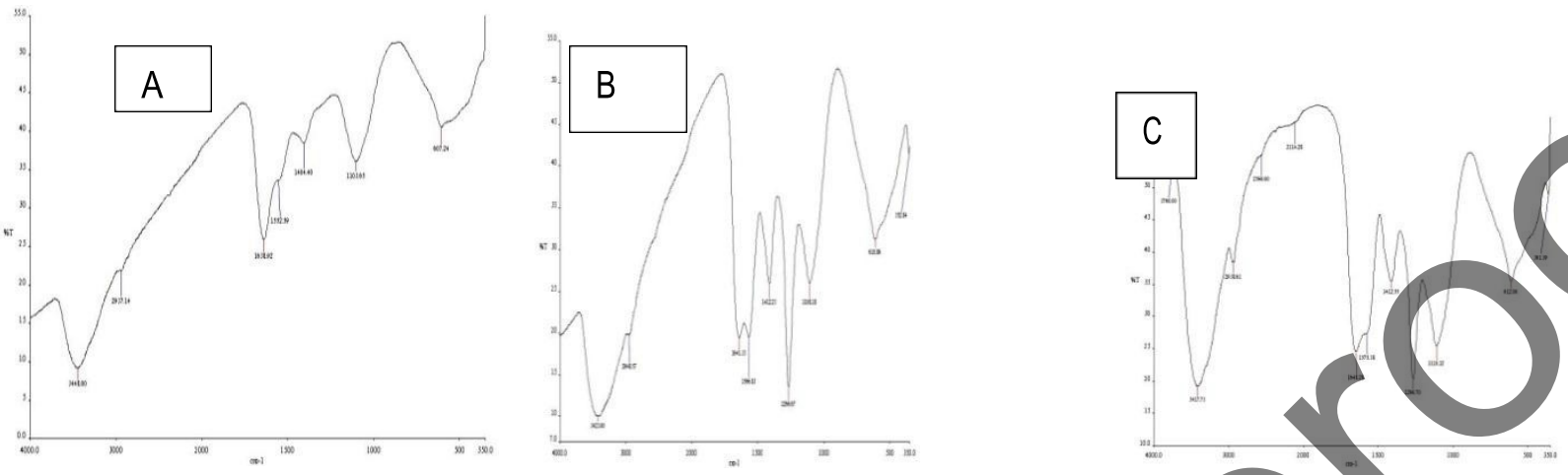

Figure 3a - c: FTIR Spectra of the SNPs from Bacillus spp. (A) BAC1-SNPs, (B)

BAC7- SNPs and (C) BAC20-SNPs

The Fourier Transform Infra-Red (FTIR) measurements were carried out to identify possible interactions between silver salts and protein molecule. FTIR is very useful for SNPs characterization as reported by Kanmani and Lim ${ }^{34}$. El-Batal et al. ${ }^{35}$ reported that the release of extracellular protein molecules from bacteria could possibly perform

348 the function of formation and stabilization of SNPs in aqueous medium. Balashanmugam et al ${ }^{30}$ also suggested that from FTIR spectrum analysis, SNPs were surrounded by proteins and amino acids which may be responsible for the stability of

351 the SNPs.

352 The functional groups such as carboxylic acid, amino acid, alcohol, esters and 353 aldehydes present in the SNPs biosynthesized using the Bacillus metabolites were 354 responsible for reduction, capping and stabilization of the nanoparticles. El-Batal et al., 35535 reported functional groups as the reducing agents responsible for SNPs formation 356 and stabilization in their work.

358 Antibacterial activity of the biosynthesized SNPs from the Bacillus strains against 359 MDR Salmonella spp.

360 The antibacterial activity of the biosynthesized SNPs from the Bacillus spp. against the 361 selected MDR Salmonella spp. is shown in Figure 4. 
BAC7-SNPs and BAC20-SNPs exhibited higher activity against the MDRSA9 compare to $\mathrm{AgNO}_{3}$. Ciprofloxacin exhibited the highest activity against MDRSA9 compare to the SNPS.

Antibacterial activity of BAC1-SNPs, BAC7-SNPs and BAC20-SNPs against MDRSA18 ranged from $11-20 \mathrm{~nm}$. All the biosynthesized SNPs had antagonistic activity against MDRSA18. Comparatively, the BAC7-SNPs exhibited highest antagonistic activity 371 against MDRSA18 than BAC1-SNPs and BAC20-SNPs.

372 Comparatively, BAC1-SNPs had the antagonistic potential against MDRSA9 while 373 BAC7-SNPs and BAC20-SNPs had highest antagonistic potential against MDRSA18. 374 Ciprofloxacin exhibited the highest activity against MDRS18 compare to the SNPs.

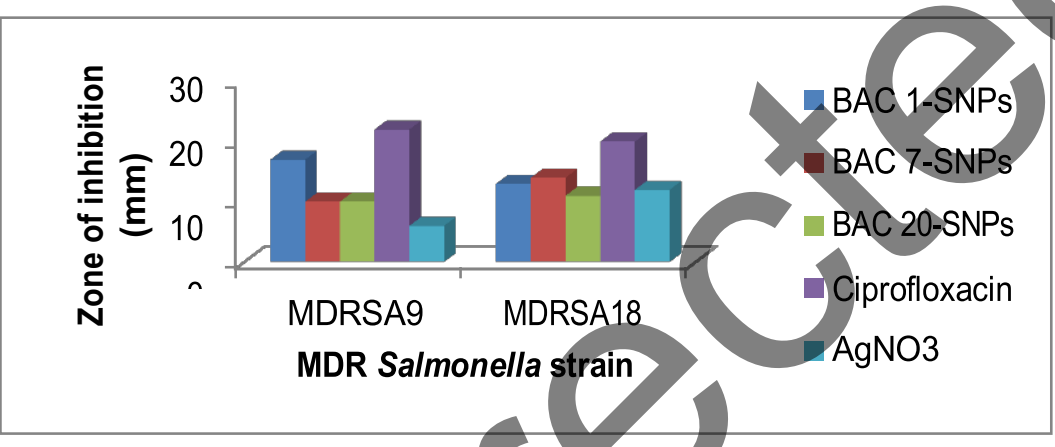

377 Figure 4: Antibacterial activity of the synthesized SNPs against the selected (MDR)

\section{Salmonella spp.}

380 Guzman et al. ${ }^{41}$ reported the possibility of SNPs acting similarly to the antimicrobial 381 agents used for the treatment of bacterial infections, which show four different 382 mechanisms of action including; interference with cell wall synthesis, inhibition of protein 383 synthesis, interference with nucleic acid synthesis and inhibition of metabolic pathway. 384 Sharma et al. ${ }^{42}$ also noted that SNPs not only interact with the surface of the 385 membrane, but can also penetrate inside the bacteria. It is reported that the bactericidal effect of silver nanoparticles decreases as the size increases and is also affected by the 
387 shape of the particles. Dhanalakshmi and Rajendran ${ }^{43}$ reported the interaction of

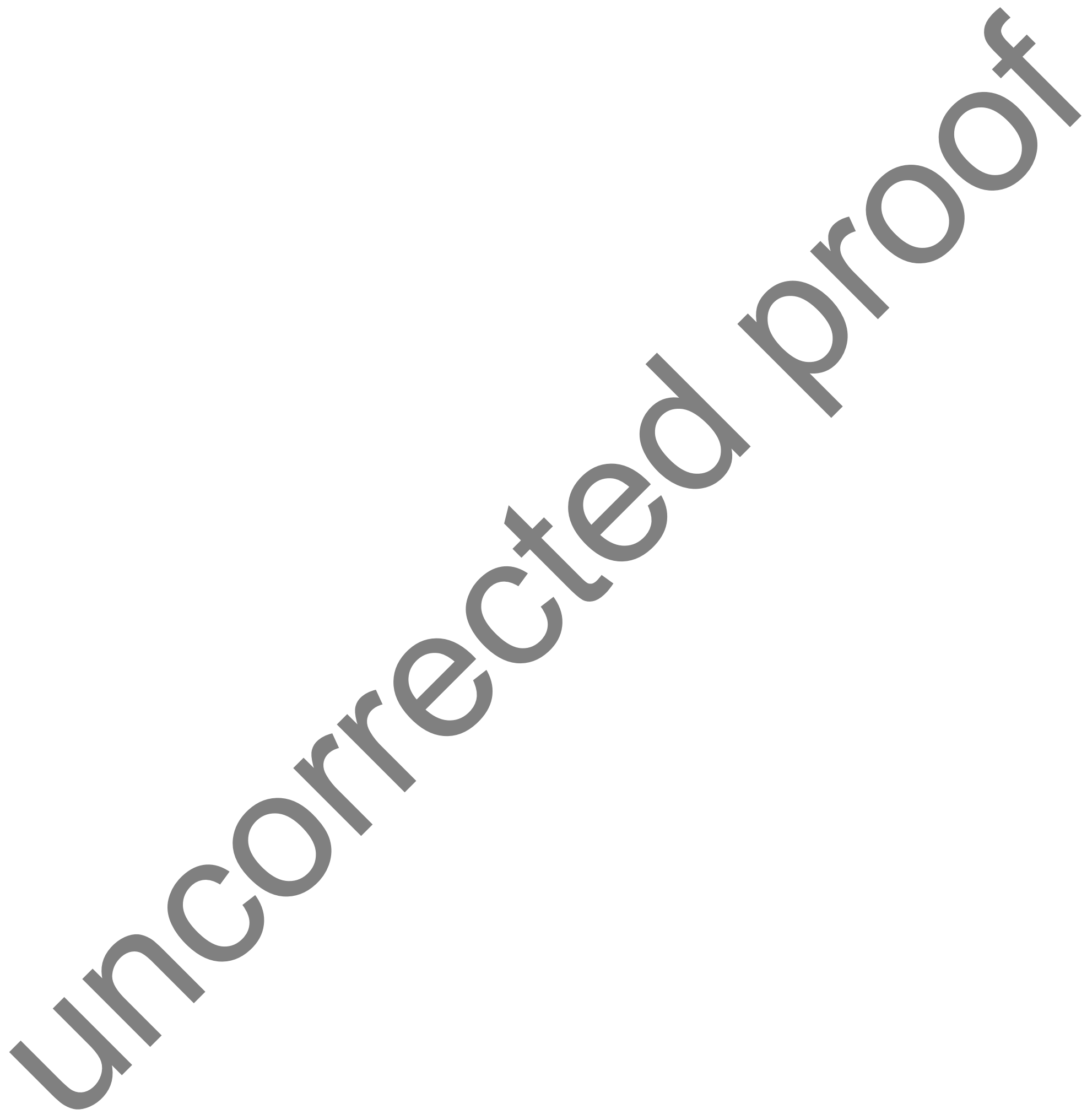


nanoparticles with the DNA inside a bacterium thus losing its ability to replicate which

389 may lead to the cell death.

390 Antibacterial activities of the SNPs produced from Bacillus spp. Metabolites against 391 multi-drug resistant Salmonella spp. is in agreement with the work of Natarajan and 392 Selvaraj ${ }^{44}$ who reported the antibacterial activity of the SNPs produced from Bacillus subtilis against pathogens like Escherichia coli, Staphylococcus epidermidis, Staphylococcus coagulase positive, Serratia spp. and Salmonella typhi. They also stated that the SNPs showed the most activity against Salmonella typhi. This is not in accordance with Kanmani and $\operatorname{Lim}^{45}$ that reported that Gram negative bacteria were more susceptible to SNPs than the Gram positive bacteria.

\section{MIC of the SNPs against the MDR Salmnella spp.}

The MIC of the SNPs against the MDR Salmonella spp. is shown in Table 2. BAC1SNPs had MIC of $3.25 \mu \mathrm{g} / \mathrm{mL}$ on SA9 and $6.25 \mu \mathrm{g} / \mathrm{mL}$ on SA18. BAC7-SNPs had MIC of $3.25 \mu \mathrm{g} / \mathrm{mL}$ on SA9 and of $6.25 \mu \mathrm{g} / \mathrm{mL}$ on SA18. The BAC20-SNPs had MIC of 6.25 $\mu \mathrm{g} / \mathrm{mL}$ on SA9 and $3.25 \mu \mathrm{g} / \mathrm{mL}$ on SA18. The Salmonella sp. SA9 was resistant to BAC20-SNPs at concentration of $3.25 \mu \mathrm{g} / \mathrm{mL}$ while Salmonella sp. SA18 was resistant to BAC1-SNPs and BAC7-SNPs at $3.25 \mu \mathrm{g} / \mathrm{mL}$ concentration.

Table 2: Determination of MIC of Bacillus spp. SNPs on the selected MDR Salmonella 406 spp.

407

\begin{tabular}{cccc|ccc}
\hline \multirow{2}{*}{$\begin{array}{c}\text { MIC } \\
\text { Concentration }\end{array}(\mu \mathrm{g} / \mathrm{mL})$} & \multicolumn{5}{c}{ Zones of Inhibition $(\mathrm{mm})$} \\
\cline { 2 - 6 } & BAC1 & BAC7- & BAC20- & BAC1- & BAC7- & BAC20- \\
& - & SNPs & SNPs & SNPs & SNPs & SNPs \\
& SNPs & & & & & \\
\hline 50 & $13 \pm 0$. & $14.0 \pm 0$. & $12.0 \pm 0$. & $10.0 \pm 0$. & $12.0 \pm 1$. & $8.0 \pm 0.5^{\mathrm{c}}$ \\
& $0^{\mathrm{ab}}$ & $2^{\mathrm{a}}$ & $7^{\mathrm{b}}$ & $0^{\mathrm{b}}$ & $0^{\mathrm{a}}$ & \\
& $12 \pm 0$. & $14.0 \pm 0$. & $10.0 \pm 1$. & $12.0 \pm 0$. & $10.0 \pm 0$. & $10.0 \pm 0$. \\
& $4^{\mathrm{b}}$ & $5^{\mathrm{a}}$ & $0^{\mathrm{c}}$ & $2^{\mathrm{a}}$ & $0^{\mathrm{b}}$ & $3^{\mathrm{b}}$ \\
& $9.0 \pm 1$ & $12.0 \pm 0$. & $12.0 \pm 0$. & $9.0 \pm 0.6$ & $8.0 \pm 1.0$ & $6.0 \pm 1.0^{\mathrm{c}}$ \\
& $.0^{\mathrm{b}}$ & $6^{\mathrm{a}}$ & $0^{\mathrm{a}}$ & $0^{\mathrm{a}}$ & $\mathrm{b}^{\mathrm{b}}$ & \\
& $6.0 \pm 1$ & $8.0 \pm 0.0$ & $5.0 \pm 0.3^{\mathrm{c}}$ & $5.0 \pm 1.0$ & $4.0 \pm 0.1$ & $4.0 \pm 0.1$
\end{tabular}




\begin{tabular}{cccc|ccc} 
& $.0^{\mathrm{b}}$ & $\mathrm{a}$ & & $\mathrm{a}$ & $\mathrm{b}$ & $5^{\mathrm{b}}$ \\
3.25 & $4.0 \pm 0$ & $5.0 \pm 0.5$ & $0.0 \pm 0.0^{\mathrm{c}}$ & $0.0 \pm 0.0$ & $0.0 \pm 0.0$ & $2.0 \pm 1.0$ \\
& $.2^{\mathrm{b}}$ & $\frac{\mathrm{a}}{\mathrm{b}}$ & & $\frac{\mathrm{b}}{\mathrm{a}}$ & \\
rofloxacin & $12.0 \pm$ & $14.0 \pm 0$. & $4.0 \pm 0.2^{\mathrm{c}}$ & $10.0 \pm 0$. & $10.0 \pm 0$. & $1.0 \pm 0.5$ \\
& $0.5^{\mathrm{b}}$ & $0^{\mathrm{a}}$ & & $8^{\mathrm{a}}$ & $0^{\mathrm{a}}$ & $\frac{\mathrm{b}}{}$
\end{tabular}

408 Values are Means \pm Standard Deviations of triplicate observations. Means with different 409 alphabets across the row respectively are statistically significant at $p \leq 0.05$.

The Minimum Inhibitory Concentration (MIC) was defined as the lowest concentration of

413 the SNPs that can have antimicrobial effect on the test organisms. $10 \mathrm{mM}$ was used to 414 prepare the different concentrations of the SNPs for the MIC evaluation, different MICs 415 were recorded for the two (MDR) Salmonella spp. Balashanmugam et al. ${ }^{30}$ also 416 reported the MIC of their SNPs after testing on some pathogens with Escherichia coli and Bacillus subtilis having the highest values.

\section{EFFECT OF TEMPERATURE ON SNPS BIOSYNTHESIS}

421 The effect of temperature $\left(25-40^{\circ} \mathrm{C}\right), \mathrm{pH}(4-9)$ and different concentration of $\mathrm{AgNO}_{3}$

$422(2-10 \mathrm{Mm})$ on the biosynthesis of SNPs was evaluated and the SNPs was

423 characterized.

424 UV-Visible spectra of BAC1-SNPs had a sharp SPR peak at 400 and 800 at $25^{\circ} \mathrm{C}$ and $42535^{\circ} \mathrm{C}$. At $40^{\circ} \mathrm{C}$, a sharp SRP was observed at $600 \mathrm{~nm}$. SNPs synthesized at $35^{\circ} \mathrm{C}$ had 426 the highest SPR peak. (Figure 5a). BAC7- SNPs biosynthesized at $25^{\circ} \mathrm{C}, 35^{\circ} \mathrm{C}$ and $42740^{\circ} \mathrm{C}$, the sharp SPR peak was observed at $400 \mathrm{~nm}$ and $800 \mathrm{~nm}$ (Figure 5b). For 428 BAC20-SNP, at $25^{\circ} \mathrm{C}$ and $40^{\circ} \mathrm{C}$, the UV-Visible spectra showed a sharp SPR peak at $429400 \mathrm{~nm}$ and $800 \mathrm{~nm}$ while at $35^{\circ} \mathrm{C}$, the sharp SPR peak was observed at $600 \mathrm{~nm}$ (Figure 430 5c). Highest absorbance values were obtained at $35^{\circ} \mathrm{C}$ followed by $40^{\circ} \mathrm{C}$ for all the 431 SNPs. The optimum temperature for the production of the SNPs was $35^{\circ} \mathrm{C}$. 


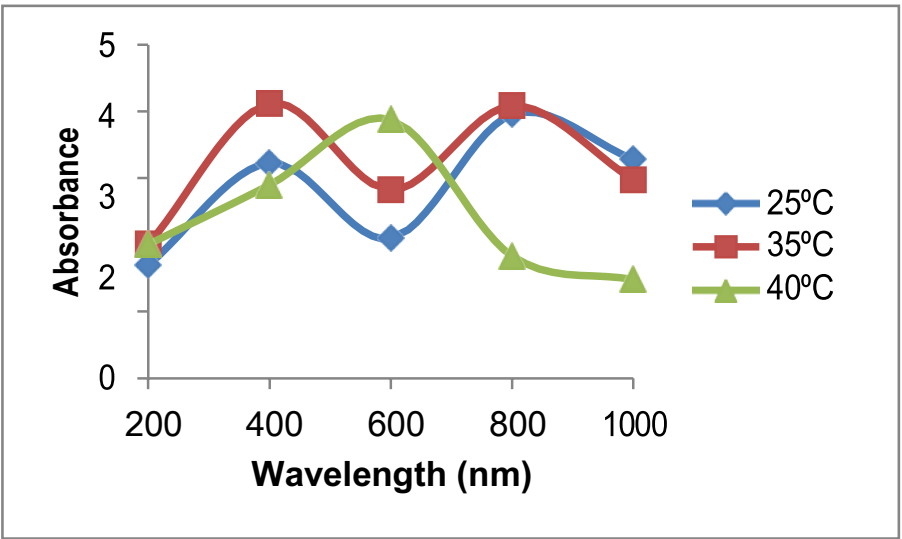

433

434 Figure 5a: UV-Visible spectra of BAC1 SNPs at different temperature
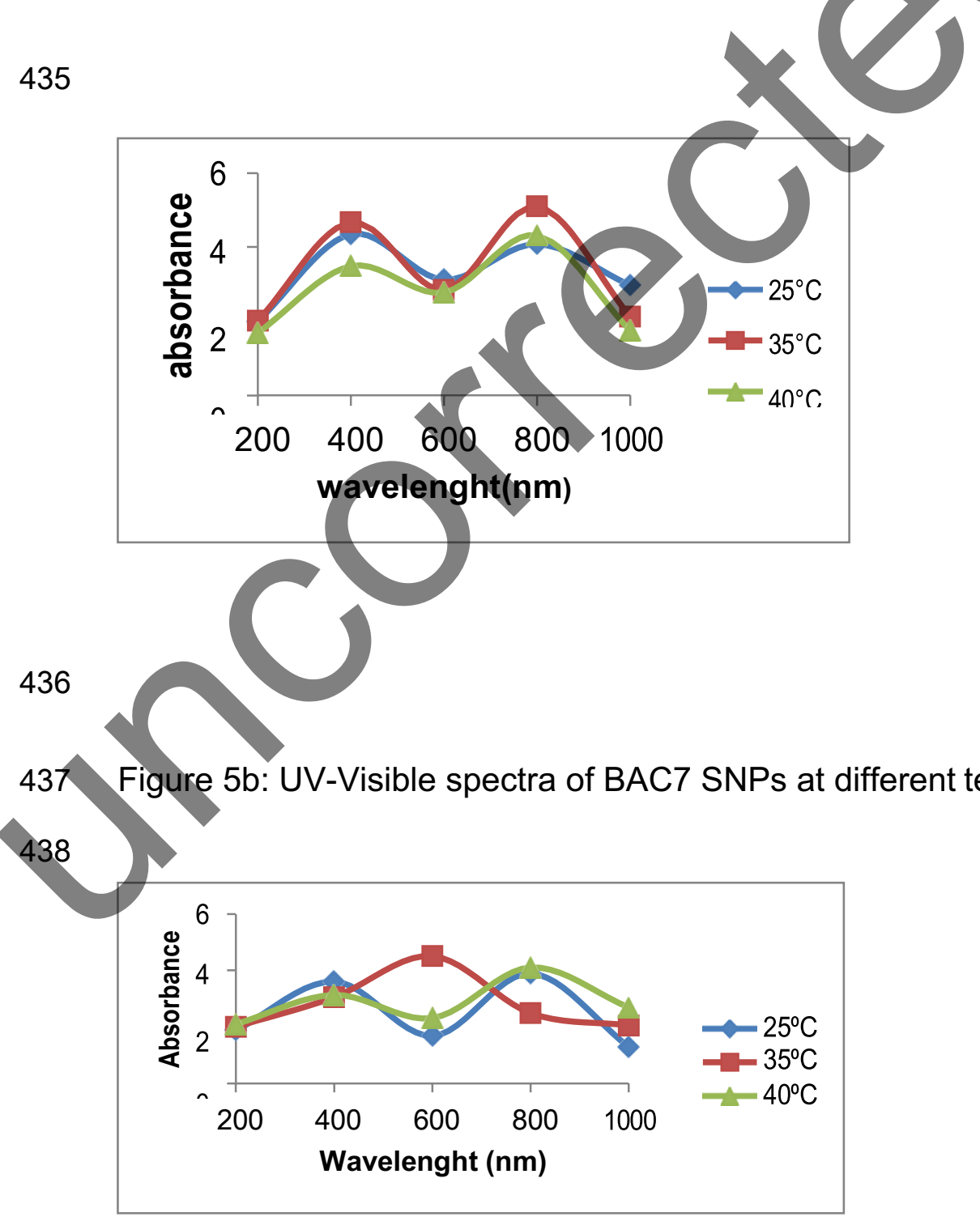
440 Figure 5c: UV-Visible spectra of BAC20 SNPs at different temperature 
441 The effect of temperature on SNPs synthesis was evaluated and the best temperature 442 for the production of SNPs was $35^{\circ} \mathrm{C}$. This is not in accordance to the work of 443 Muhammad Amin et al. ${ }^{45}$ who observed that with increase in temperature from $25^{\circ} \mathrm{C}$ to $44445^{\circ} \mathrm{C}$, the SPR peaks became sharper, an absorption band at $406 \mathrm{~nm}$ was obtained 445 which suggested the formation of SNPs.

446 Annadurai et al., ${ }^{46}$ also reported that the synthesis of silver nanoparticles from leaf

447 extract of Coleus aromaticus increases when the reaction temperature was increased 448 and they concluded that higher temperature $\left(70^{\circ} \mathrm{C}\right)$ was best for hanoparticles 449 synthesis. Muhammad Amin et al., ${ }^{45}$ observed that the best temperature required for 450 the completion of reaction was investigated to be $45^{\circ} \mathrm{C}$

\section{EFFECT OF pH ON SNPs BIOSYNTHESIS}

453 The UV - spectra of the effect of different $\mathrm{pH}(4,7$ and 9$)$ on SNPs biosynthesis is 454 shown in Figure $6(\mathrm{a}-\mathrm{c})$. The UV-Visible spectra of BAC1- SNPs produced at different $455 \mathrm{pH}$ is shown in Figure 6a. at $\mathrm{pH} 4$ and 7, a sharp peak was observed at 600nm while 456 at $\mathrm{pH}$ 9, sharp SPR peak was observed at $400 \mathrm{~nm}$. The highest absorbance was 457 observed at $\mathrm{pH} 7$. The UY-Visible spectra of BAC7-SNPs at pH4, $\mathrm{pH} 7$ and $\mathrm{pH} 9$ had a 458 broad spectrum between $400 \mathrm{~nm}$ and $800 \mathrm{~nm}$. BAC7-SNPs at $\mathrm{pH} 7$ had a sharp peak at $459200 \mathrm{~nm}$ (Figure 6b). The UV-Visible spectra of BAC20-SNPs biosynthesized at different $460 \mathrm{pH}$ is shown in Figure 5c. BAC20-SNPs had highest sharp SPR peak at $600 \mathrm{~nm}$. The 461 SNPs biosynthesized at $\mathrm{pH} 4$ and 7 has a broad band between $600 \mathrm{~nm}$ and $800 \mathrm{~nm}$. 
464
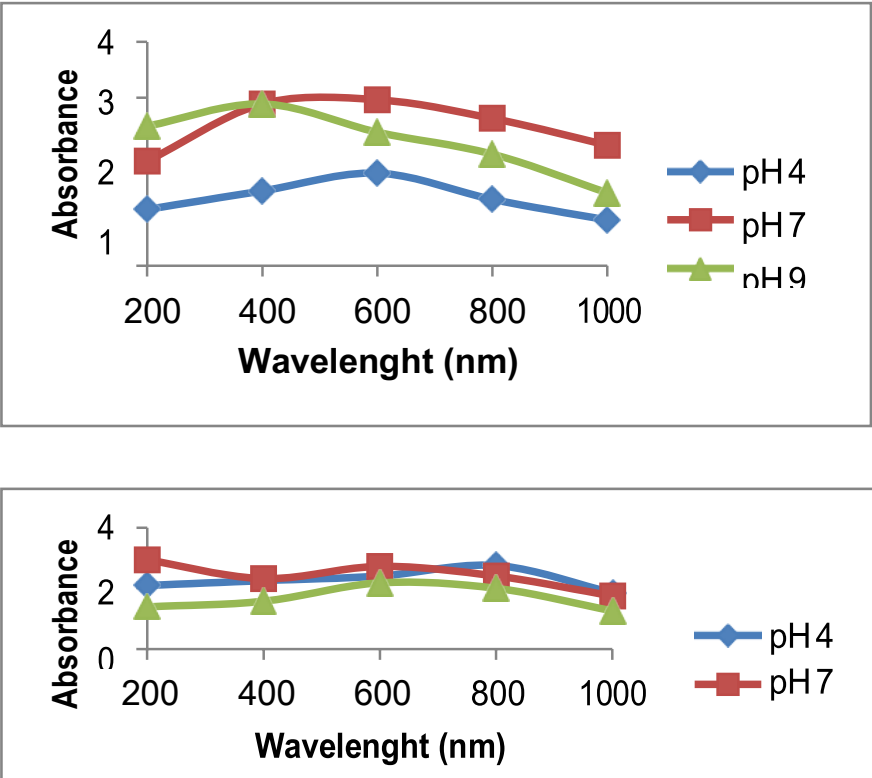

465

466

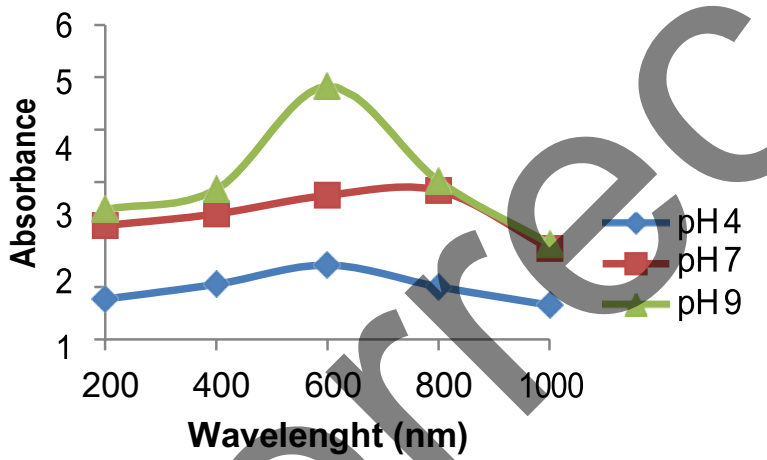

467 Figure 6(a-c): UV-Visible spectra of SNPs biosynthesized at different pH by Bacillus 468 spp. A), BAC1-SNPs, B) BAC7-SNPs and C) BAC20 SNPs.

469 The optimum pH for the production of SNPs by Bacillus spp. fermentation broth was at $470 \mathrm{pH}$ 7. Goldie Oza et al. [46] reported the optimum pH for extracellular fabrication of 471 silver nanoparticles using Pseudomonas aeruginosa was pH10. Annadurai et al. (47) 472 reported that the alkaline $\mathrm{pH}$ was more suitable for SNPs synthesis by Coleus 473 aromaticus. Amin et al. (45) reported more SNP biosynthesized under basic conditions 
474 while the formation of SNPs was repressed by acidic conditions and at lower $\mathrm{pH}(\mathrm{pH} 5)$, 475 larger nanoparticles were formed, whereas, at higher $\mathrm{pH}(\mathrm{pH} 9)$, smaller and highly 476 dispersed nanoparticles were formed. 
478 Antimicrobial potential of $\mathrm{AgNO}_{3}$ and $\mathrm{SNPs}$ biosynthesized at different pH against MDR479 Salmonella spp.

480

481

482

483

484

485

486

487

488

489

490

491

492

493

494

The antimicrobial activity of the SNPs biosynthesized at different pH against the MDRSA9 is shown in Table 3a. All the $\mathrm{AgNO}_{3}$ and the SNPs had antimicrobial activity against MDR-SA9.

The antibacterial activity of BAC1-SNPs, BAC7-SNPs and BAC20-SNPs at pH 4, pH7 and $\mathrm{pH} 9$ against MDR-SA9 ranged from $8-16 \mathrm{~mm}, 4-14 \mathrm{~mm}$ and 4- 14mm. BAC1SNPs produced at $\mathrm{pH} 9$ and BAC7-SNPs and BAC20-SNPs produced at $\mathrm{pH} 7$ exhibited the highest antagonistic activity against MDR-SA9.

Antimicrobial activity of the SNPs biosynthesized at different pHby Bacillus spp. against MDR-SA18 is shown in Table 3b. The SNPs had antimicrobial activity against MDRSA18 at different $\mathrm{pH}$. The antimicrobial activity of BAC1-SNPs, BAC7-SNPs BAC20SNPs against MDR-SA18 ranged from 4.0-9.0 mm, $4.0-9.0 \mathrm{~mm}$ and $3.0-10 \mathrm{~mm}$. The highest activity was recorded at $\mathrm{pH} 7$. There was no zone of inhibition at $\mathrm{pH} 9$ by BAC1-SNPs and BAC7-SNPs against MDR-SA18 at 24 hrs of incubation.

Table 3a: The antimicrobial potential of $\mathrm{AgNO}_{3}$ and SNPs biosynthesized at different $\mathrm{pH}$ against MDR-SA9.

\begin{tabular}{lllllll}
\hline Samples & \multicolumn{5}{c}{ Antimicrobial activity $(\mathrm{mm})$} \\
\cline { 2 - 7 } & \multicolumn{1}{c}{ BAC1-SNPs SA9 } & \multicolumn{2}{c}{ BAC7-SNPs } & \multicolumn{2}{c}{ BAC20-SNPs } \\
\cline { 2 - 7 } & $24 \mathrm{hrs}$ & $48 \mathrm{hrs}$ & $24 \mathrm{hrs}$ & $48 \mathrm{hrs}$ & $24 \mathrm{hrs}$ & $48 \mathrm{hrs}$ \\
\hline SNPs pH4 & $10.0 \pm 1.0^{\mathrm{a}}$ & $8.0 \pm 1.0^{\mathrm{b}}$ & $4.0 \pm 0.0^{\mathrm{d}}$ & $4.0 \pm 0.0^{\mathrm{d}}$ & $7.0 \pm 0.3^{\mathrm{c}}$ & $4.0 \pm 1.0^{\mathrm{d}}$ \\
SNPs pH7 & $12.0 \pm 0.5^{\mathrm{b}}$ & $10.0 \pm 0.0^{\mathrm{b}}$ & $14.0 \pm 1.0^{\mathrm{a}}$ & $12.0 \pm 0.5^{\mathrm{b}}$ & $14.0 \pm 0.5^{\mathrm{a}}$ & $11.0 \pm 0.0^{\mathrm{bc}}$ \\
SNPs pH9 & $14.0 \pm 0.2^{\mathrm{b}}$ & $16.0 \pm 0.2^{\mathrm{a}}$ & $12.0 \pm 0.3^{\mathrm{c}}$ & $9.0 \pm 0.4^{\mathrm{d}}$ & $6.0 \pm 0.0^{\mathrm{f}}$ & $8.0 \pm 0.5^{\mathrm{e}}$
\end{tabular}

495 Values are Means \pm Standard Deviations of triplicate observations. Means with different 496 alphabets across the row respectively are statistically significant at $p \leq 0.05$.

497 Table 3b: The antimicrobial potential of $\mathrm{AgNO}_{3}$ and SNPs biosynthesized at different $\mathrm{pH}$ 498 against MDR-SA18. 


\begin{tabular}{|c|c|c|c|c|c|c|}
\hline \multirow[t]{3}{*}{ Samples } & \multicolumn{6}{|c|}{ Antimicrobial activity $(\mathrm{mm})$} \\
\hline & \multicolumn{2}{|c|}{ BAC1-SNPs } & \multicolumn{2}{|c|}{ BAC7-SNPs } & \multicolumn{2}{|c|}{ BAC20-SNPs } \\
\hline & $24 \mathrm{hrs}$ & $48 \mathrm{hrs}$ & $24 \mathrm{hrs}$ & $48 \mathrm{hrs}$ & $24 \mathrm{hrs}$ & 48hrs \\
\hline SNPs pH4 & $4.0 \pm 0.0^{c}$ & $6.0 \pm 0.5^{b}$ & $7.0 \pm 0.2^{\mathrm{a}}$ & $4.0 \pm 0 .^{c}$ & $2.0 \pm 0.2^{d}$ & $6.0 \pm 0.2^{b}$ \\
\hline SNPs pH7 & $9.0 \pm 0.4^{b}$ & $8.0 \pm 0.00^{c}$ & $6.0 \pm 0.0^{d}$ & $9.0 \pm 0.2^{b}$ & $6.0 \pm 0.50^{d}$ & $10.0 \pm 0.4^{a}$ \\
\hline SNPs pH9 & $0.0 \pm 0.0^{d}$ & $3.0 \pm 0.2^{c}$ & $0.0 \pm 0.0^{d}$ & $4.0 \pm 0.0^{b}$ & $5.0 \pm 0.2^{a}$ & $3.0 \pm 0.27^{c}$ \\
\hline
\end{tabular}

Values are Means \pm Standard Deviations of triplicate observations. Means with different

500 alphabets across the row respectively are statistically significant at $p \leq 0.05$.

\section{Effect of different concentrations of $\mathrm{AgNO}_{3}$ on the SNPs biosynthesis}

503 The effect of different concentrations $(2-10 \mathrm{mM})$ of silver nitrate $\left(\mathrm{AgNO}_{3}\right)$ solutions on

504 biosynthesis of SNPs was evaluated and was monitored with UV-Visible

505 spectrophotometer. Figure 7a shows the spectra of BAC1-SNPs produced at different

506 concentrations of silver nitrate. SPR peak was observed at $400 \mathrm{~nm}$ for Bacillus sp. BAC1

507 SNPs produced with $8 \mathrm{mM}$. The SNPs produce with $2 \mathrm{mM}$ and $4 \mathrm{mM}$ of $\mathrm{AgNO}_{3}$ had

508 abroad band between $400 \mathrm{~nm}$ and $800 \mathrm{~nm}$. The SNPs produced with $10 \mathrm{mM} \mathrm{AgNO}_{3}$ a

509 strong SPR peak at $600 \mathrm{~nm}$.

510 The spectra obtained for BAC7 SNPs produced with different concentrations of $\mathrm{AgNO}_{3}$

511 was shown in Figure $7 \mathrm{~b}$. A broad band spectrum between $400 \mathrm{~nm}$ and $600 \mathrm{~nm}$ was

512 observed for the SNPs synthesized with $2 \mathrm{mM}, 6 \mathrm{mM}$ and $8 \mathrm{mM}$ concentrations of

$513 \mathrm{AgNO}_{3}$. The SNPs produced with the $10 \mathrm{mM} \mathrm{AgNO} 3$ has a strong peak at $600 \mathrm{~nm}$. The

$51410 \mathrm{mM} \mathrm{AgNO}_{3}$ concentration had the highest OD.

515 The effect of concentration on biosynthesis of Bacillus sp. BAC20 SNPs was presented 516 in Figure $7 \mathrm{c}$. The SNPs produced with $2 \mathrm{Mm}$ to $10 \mathrm{mM} \mathrm{AgNO}_{3}$ concentration all had a 517 broad band spectrum between $400 \mathrm{~nm}$ and $800 \mathrm{~nm}$. A SPR peak of $600 \mathrm{~nm}$ was 518 observed for $2 \mathrm{mM}, 4 \mathrm{mM}$ and $6 \mathrm{mM}$. The highest OD was shown by the SNPs produced 519 with $10 \mathrm{mM}$ at $500 \mathrm{~nm}$. 


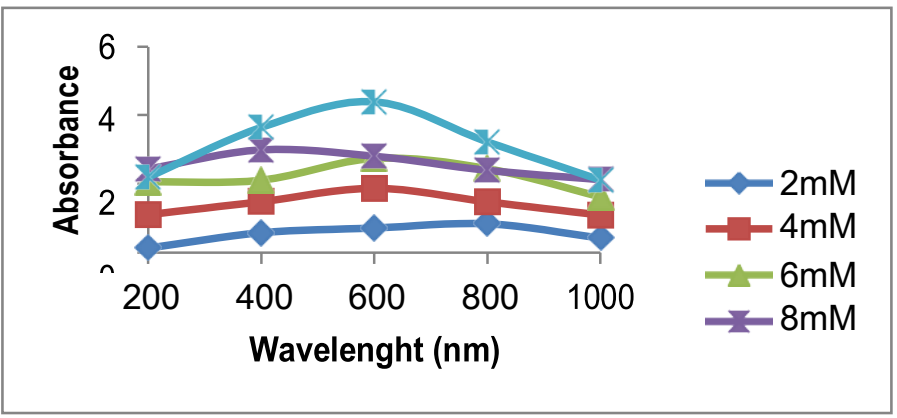

524 Figure 7a: UV-Visible spectra of BAC1 SNPs at different concentrations of AgNO

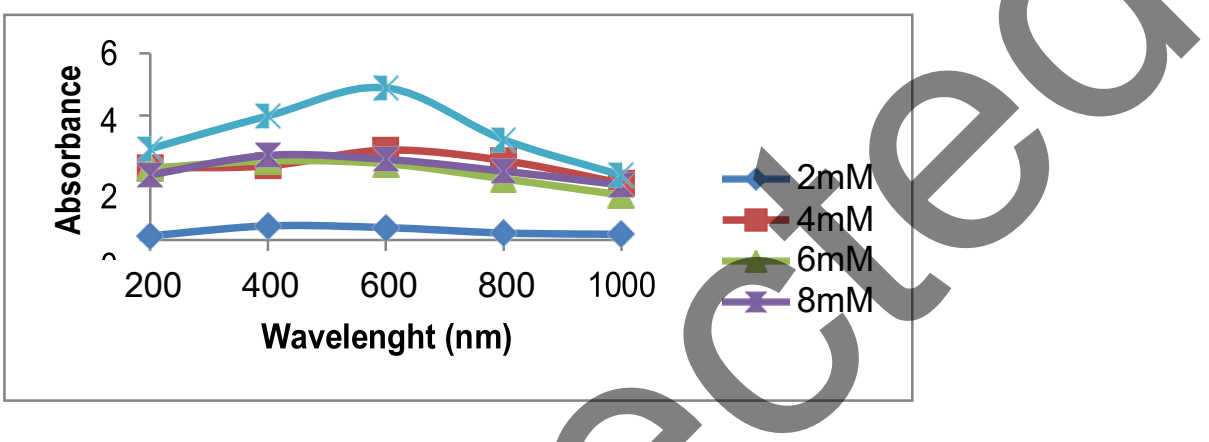

Figure 7b: UV-Visible spectra of BAC7 SNPs at different concentrations of $\mathrm{AgNO}_{3}$

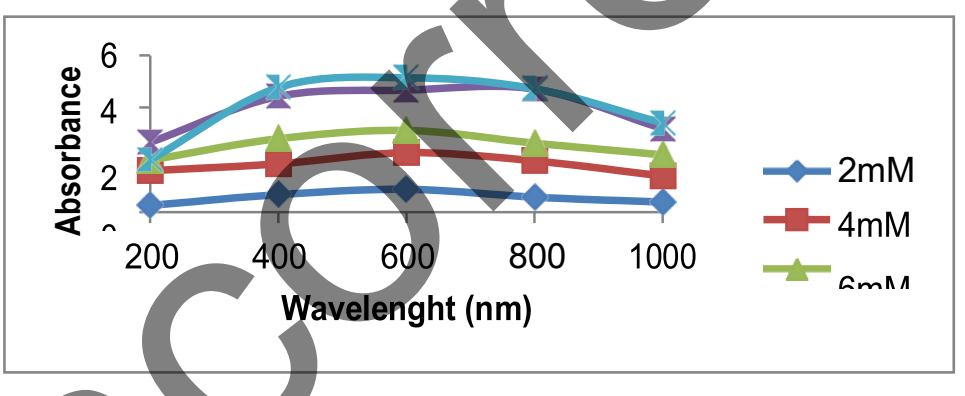

Figure 7c: UV-Visible spectra of BAC20 SNPs at different concentrations of $\mathrm{AgNO}_{3}$ 


\section{$531 \quad \mathrm{AgNO}_{3}$}

532 The antimicrobial activity of the SNPs biosynthesized by Bacillus spp. using different 533 concentration of $\mathrm{AgNO}_{3}$ is shown in Table $4 \mathrm{a}-\mathrm{b}$. 
534 All the SNPs produced by Bacillus spp. using different concentration of $\mathrm{AgNO}_{3}$ had 535 antagonistic activity against the isolates. The antimicrobial activity of BAC1-SNPs 536 BAC7-SNPs and BAC20-SNPs against MDR-SA9 ranged from 6-24 mm, $2-25 \mathrm{~mm}$ and $5372-20 \mathrm{~mm}$ at 24,48 and $72 \mathrm{hrs}$ of incubation. $10 \mathrm{mM} \mathrm{AgNO}_{3}$ had the highest 538 antagonistic activity $(15 \mathrm{~mm})$ against SA9.

539 The antimicrobial activity of BAC1-SNPs, BAC7-SNPs and BAC20-SNPs against MDR540 SA18 ranged from $2.0-15 \mathrm{~mm}, 2.0-17 \mathrm{~mm}$ and $2.0-21 \mathrm{~mm}$. The SNPS from the 541 Bacillus spp. had the highest activity against MDR-SA18 at $10 \mathrm{mM}$ concentration of $542 \mathrm{AgNO}_{3}$.

544 Table 4a: Antimicrobial potential of SNPs biosynthesized using different concentration 545 of $\mathrm{AgNO}_{3}$ against MRD-SA9 at different incubation time

\begin{tabular}{|c|c|c|c|c|c|c|c|c|c|}
\hline \multicolumn{10}{|c|}{ Zone of inhibition $(\mathrm{mm})$ / Incubation time (hrs) against MDRSA9 } \\
\hline \multirow{3}{*}{$\begin{array}{l}\text { Concentr } \\
\text { ations of } \\
\mathrm{AgNO}_{3} .\end{array}$} & \multicolumn{3}{|c|}{ BAC1-SNPs } & \multicolumn{3}{|c|}{ AC7-SNPS } & \multicolumn{3}{|c|}{ BAC20-SNPS } \\
\hline & $24 \mathrm{hrs}$ & & & & 48hrs & $72 \mathrm{hrs}$ & $24 \mathrm{hrs}$ & $48 \mathrm{hhr}$ & $72 \mathrm{hrs}$ \\
\hline & & & & & & & & $\mathrm{s}$ & \\
\hline \multirow[t]{2}{*}{$2 \mathrm{mM}$} & 0.0 & & & $4.0 \pm 0$ & $8.0 \pm 0$. & $14.0 \pm$ & $12.0 \pm$ & $6.0 \pm 0$. & $10.0 \pm$ \\
\hline & $5^{\mathrm{e}}$ & & & $2^{f}$ & $0^{d}$ & $0.0^{\mathrm{a}}$ & $0.3^{b}$ & $0^{\mathrm{e}}$ & $1.0^{c}$ \\
\hline \multirow[t]{2}{*}{$4 \mathrm{mM}$} & & & 12. & $14.0 \pm 0$ & $10.0 \pm$ & $12.0 \pm$ & $18.0 \pm$ & $10.0 \pm$ & $8.0 \pm 0$. \\
\hline & & & $.0^{\mathrm{d}}$ & $.45^{\mathrm{c}}$ & $1.0^{\mathrm{e}}$ & $1.0^{\mathrm{d}}$ & $0.0^{\mathrm{b}}$ & $0.0^{\mathrm{e}}$ & $0^{f}$ \\
\hline \multirow[t]{6}{*}{$6 \mathrm{mM}$} & & $0 \pm$ & $16.0 \pm 1$ & $2.0 \pm 0$ & $10.0 \pm$ & $16.0 \pm$ & $4.0 \pm 0$ & $10.0 \pm$ & $18.0 \pm$ \\
\hline & & $0.3^{b}$ & $.0^{c}$ & $0^{g}$ & $0.5^{\mathrm{e}}$ & $0.5^{c}$ & $10^{f}$ & $0.0^{\mathrm{e}}$ & $0.5^{\mathrm{a}}$ \\
\hline & 6. & $16.0 \pm$ & $18.0 \pm 0$ & $6.0 \pm 0$ & $12.0 \pm$ & $14.0 \pm$ & $2.0 \pm 0$ & $20.0 \pm$ & $12.0 \pm$ \\
\hline & $6^{f}$ & $0.0^{c}$ & $.53^{\mathrm{b}}$ & $2^{f}$ & $0.2^{\mathrm{e}}$ & $0.3^{d}$ & $0^{g}$ & $1.0^{\mathrm{a}}$ & $1.0^{\mathrm{e}}$ \\
\hline & $10.0 \pm$ & $20.0 \pm$ & $24.0 \pm 0$ & $6.0 \pm 0$ & $22.0 \pm$ & $25.0 \pm$ & $17.0 \pm$ & $15.0 \pm$ & $20.0 \pm$ \\
\hline & $0.0^{g}$ & $1.0^{d}$ & $.25^{\mathrm{b}}$ & $0^{h}$ & $1.0^{c}$ & $0.0^{\mathrm{a}}$ & $0.6^{\mathrm{e}}$ & $0.6^{f}$ & $1.0^{\mathrm{d}}$ \\
\hline
\end{tabular}

546 Values are Means \pm Standard Deviations of triplicate observations. Means with different 547 alphabets across the row respectively are statistically significant at $p \leq 0.05$. 
Table 4b: Antimicrobial potential of SNPs biosynthesized using different concentration

549 of $\mathrm{AgNO}_{3}$ against MRD-SA18 at different incubation time

\begin{tabular}{|c|c|c|c|c|c|c|c|c|c|}
\hline \multirow{4}{*}{$\begin{array}{l}\text { Concentra } \\
\text { tions of } \\
\mathrm{AgNO}_{3} \text {. } \\
2 \mathrm{mM}\end{array}$} & \multicolumn{9}{|c|}{ Zone of inhibition (mm) / Incubation time (hrs) against MDRSA18 } \\
\hline & \multicolumn{3}{|c|}{ BAC1-SNPs } & \multicolumn{3}{|c|}{ BAC7-SNPs } & \multicolumn{3}{|c|}{ BAC20-SNPs } \\
\hline & $24 \mathrm{hrs}$ & $48 \mathrm{hrs}$ & $72 \mathrm{hrs}$ & $24 \mathrm{hrs}$ & 48hrs & $72 \mathrm{hrs}$ & $24 \mathrm{hrs}$ & $48 \mathrm{hrs}$ & \\
\hline & $\begin{array}{l}3.0 \pm 0 . \\
0^{d}\end{array}$ & $\begin{array}{l}4.0 \pm 0 . \\
3^{c}\end{array}$ & $\begin{array}{l}0.0 \pm 0 . \\
0^{e}\end{array}$ & $\begin{array}{l}4.0 \pm 1 \\
.0^{c}\end{array}$ & $\begin{array}{l}4.0 \pm 1 . \\
0^{c}\end{array}$ & $\begin{array}{l}7.0 \pm 0 . \\
2^{a}\end{array}$ & $0^{\mathrm{e}}$ & & \\
\hline $4 \mathrm{mM}$ & $\begin{array}{l}5.0 \pm 0 . \\
5^{c}\end{array}$ & $\begin{array}{l}0.0 \pm 0 . \\
0^{f}\end{array}$ & $\begin{array}{l}5.0 \pm 0 . \\
0^{c}\end{array}$ & $\begin{array}{l}2.0 \pm 0 \\
.6^{\mathrm{e}}\end{array}$ & $\begin{array}{l}3.0 \pm 0 . \\
0^{d}\end{array}$ & $\begin{array}{l}9.0 \pm 0 . \\
4^{b}\end{array}$ & & & \\
\hline $6 \mathrm{mM}$ & $\begin{array}{l}0.0 \pm 0 . \\
0^{\mathrm{e}}\end{array}$ & $\begin{array}{l}10.0 \pm \\
1.0^{\mathrm{b}}\end{array}$ & $\begin{array}{l}12.0 \pm \\
1.0^{\mathrm{a}}\end{array}$ & $\begin{array}{l}0.0 \pm 0 \\
.0^{\mathrm{e}}\end{array}$ & $\begin{array}{l}8.0 \pm 0 . \\
5^{c}\end{array}$ & $\begin{array}{l}10.0 \pm \\
0.5^{b}\end{array}$ & & & $\begin{array}{l}0.0 \pm 0 . \\
0^{e}\end{array}$ \\
\hline $8 m M$ & $\begin{array}{l}7.0 \pm 0 . \\
10^{\mathrm{e}}\end{array}$ & $\begin{array}{l}12.0 \pm \\
0.2^{\mathrm{a}}\end{array}$ & $\begin{array}{l}9.0 \pm 0 . \\
45^{c}\end{array}$ & $\begin{array}{l}8.0 \pm 1 \\
.0^{\mathrm{d}}\end{array}$ & $\begin{array}{l}4.0 \pm 0 . \\
1^{f}\end{array}$ & & $3^{d}$ & $\begin{array}{l}12.0 \pm \\
0.0^{a}\end{array}$ & $\begin{array}{l}10.0 \pm \\
1.0^{\mathrm{b}}\end{array}$ \\
\hline $10 \mathrm{mM}$ & $\begin{array}{l}13.0 \pm \\
0.6^{\mathrm{e}}\end{array}$ & $\begin{array}{l}15.0 \pm \\
0.0^{c}\end{array}$ & $\begin{array}{l}14.0 \pm \\
1.0^{\mathrm{d}}\end{array}$ & $\begin{array}{l}3.0 \pm 0 \\
.0^{\mathrm{h}}\end{array}$ & $12.0 \pm$ & & $\begin{array}{l}8.0 \pm 1 . \\
0^{g}\end{array}$ & $\begin{array}{l}12.0 \pm \\
0.0^{f}\end{array}$ & $\begin{array}{l}21.0 \pm \\
0.3^{a}\end{array}$ \\
\hline
\end{tabular}

Values are Means \pm Standard Deviations of triplicate observations. Means with different 551 alphabets across the row respectively are statistically significant at $p \leq 0.05$.

553 Synergistic effect of the biosynthesized SNPs and some antibiotics against MDR

554 Salmonella spp.

555 The synergetic effect of the biosynthesized SNPs and some antibiotic against MDR

556 Salmonella sp. SA9 and MDR Salmonella sp. SA18 is shown in Figure 8 a-b.

557 The MDRSA9 shows susceptibility to antibiotics with antagonistic potential ranged

558 between $3.0-20 \mathrm{~mm}$. Colistin had the lowest antagonistic activity while 559 chlorotetracycline had the highest activity.

560 The synergetic effect of the biosynthesized SNPs and some antibiotic against MDR-SA9 561 is shown in Figure 8a. The antagonistic potential of BAC1 SNPs + the antibiotics 562 ranged from $10-33 \mathrm{~mm}$. BAC1 SNPs + Erythromycin had the highest antagonistic 563 activity against MDR-SA9 while BAC1 SNPs + Oxytetracycline had the least activity. 
564 The antagonistic potential of BAC7-SNPs + antibiotics against MDR-SA9 ranged from $5656.0-30 \mathrm{~mm}$. BAC7-SNPs + Gentamicin had the highest activity while BAC7 SNPs + 566 Colistin had the lowest antagonistic activity. The antagonistic activity of BAC20-SNPs + 567 antibiotics against MDR-SA9 ranged from 5.0 - $31 \mathrm{~mm}$. BAC20 + Chlorotetracycline 568 had the highest antagonistic potential while BAC20-SNPs + Colistin had the least 569 activity.

570 The synergistic effect of the SNPs and the antibiotics against the MDRSA18 is shown in 571 Figure 8b. The antagonistic activity against MDR-SA18 ranged from $2.0-18 \mathrm{~mm}$. 572 Colistin had the least activity while antibiotics Gentamicin had the highest activity 573 against MDR-SA18

574 The antagonistic activity of BAC1 SNPs + the antibiotics against MDR-SA18 ranged 575 from $9.0-20 \mathrm{~mm}$ showing a high susceptibility. MDR-SA18 had the highest 576 susceptibility to BAC1 SNPs + Ciprofloxacin while the least susceptibility was to BAC1 577 SNPs + colistin.

578 The BAC7 SNPs + antibiotics had antibacterial activity ranged from $10-24 \mathrm{~mm}$ against 579 MDR-SA18. BAC7 SNPs + Gentamicin have the highest activity against MDR-SA9. The 580 antagonistic activity of BAC20 SNPs + antibiotics against MDR-SA18 ranged from 6.0 $58126 \mathrm{~mm}$. BAC20 + Erythromycin had the highest antagonistic potential while BAC20 582 SNPs + Colistin had the least.

583 The antagonistic potential of the combined BAC1- SNPs and the antibiotics against the 584 MRDSA9 and MDRS18 is shown in Table 4a -b. The antagonistic activity against the 585 MRDSA9 and MRDSA18 ranged from 3.0 -33 mm and 2.0 -20 mm. MRDSA9 was 586 highly susceptible to BAC1-SNPs +Erytromycins 


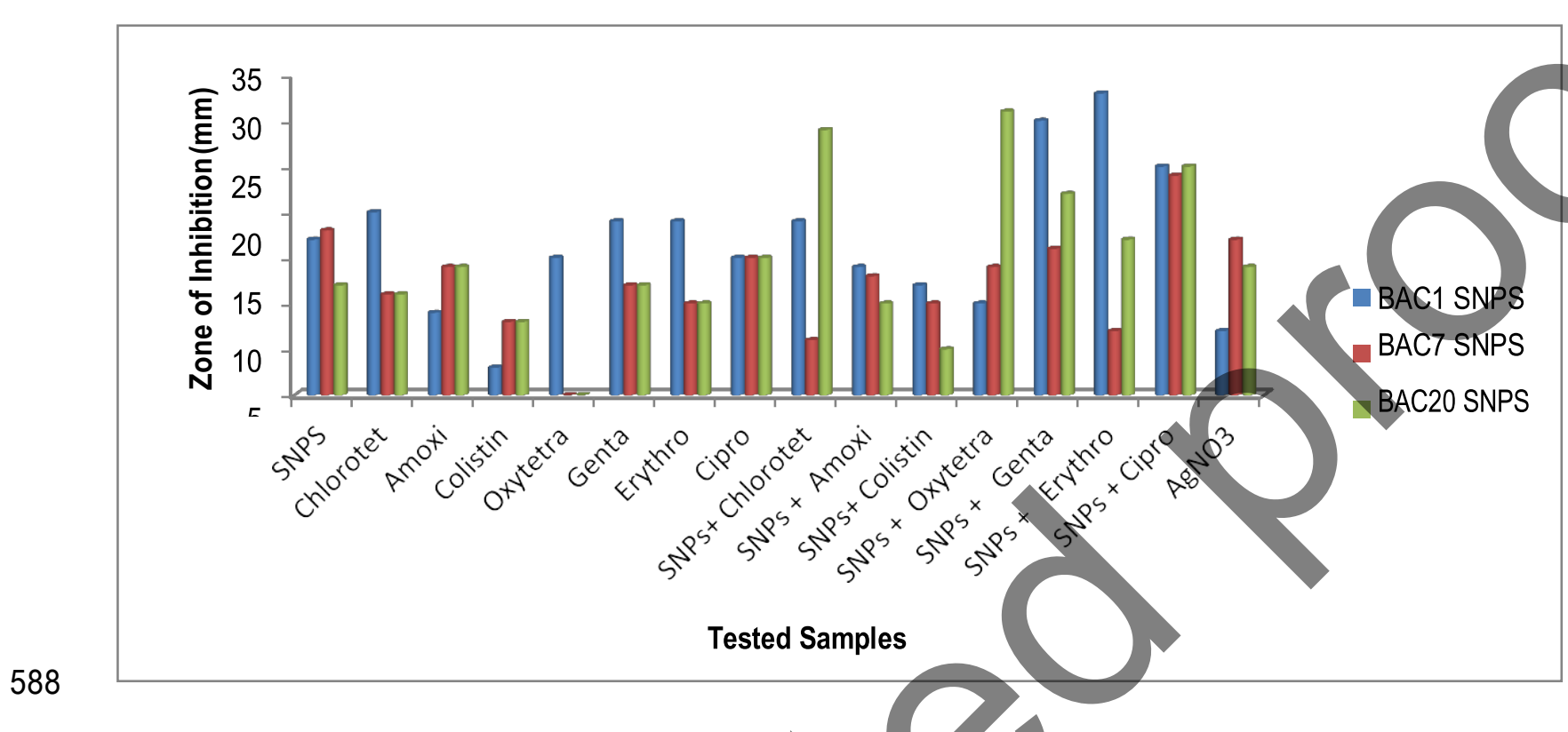

589 Figure 8a: Diameter of Zones of Inhibition in $(\mathrm{mm})$ of the of the SNPs, antibiotic and 590 combination of SNPs + antibiotics against the MDR-SA9

591

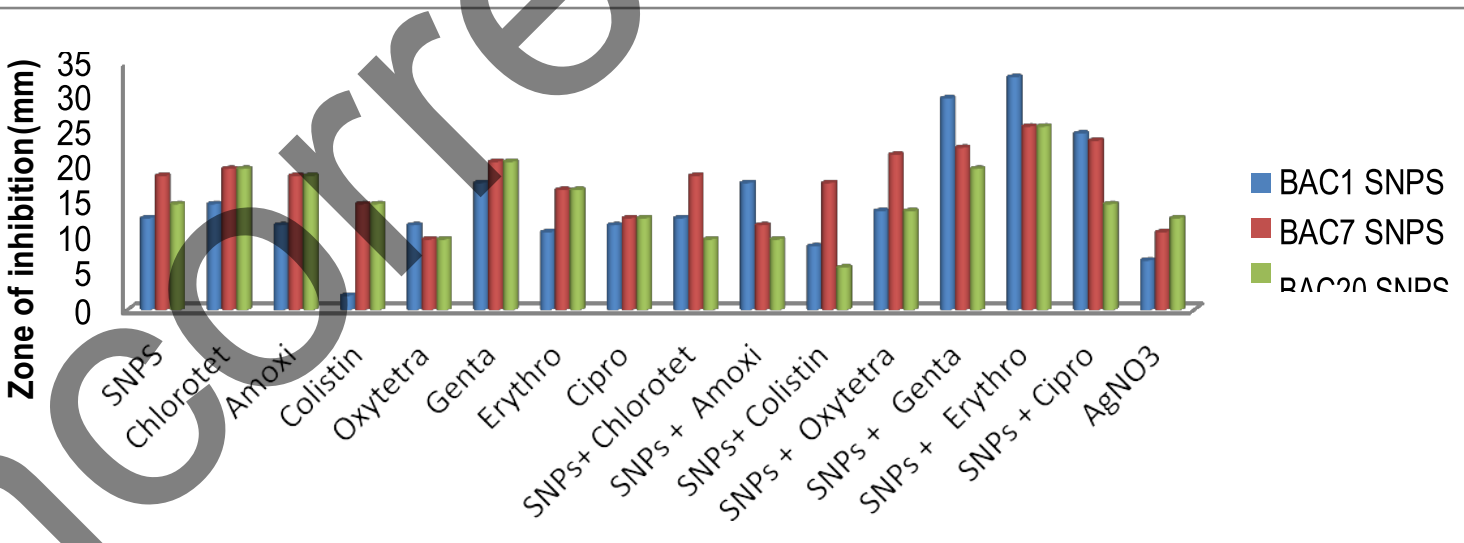

Tested samples

593 Figure 8b: Diameter of Zones of Inhibition $(\mathrm{mm})$ of the SNPs, antibiotic and combination 594 of SNPs + antibiotics against the MDR-SA18 
596 It was found that the silver nanoparticles produced from Bacillus sp. enhanced the reaction rates of the antibiotics in a synergistic mode as well as in its own way on these 
pathogens. In both the cases of Salmonella spp. (SA9) and Salmonella enterica sub 599 enterica (SA18) the highest zone of inhibition was found in the combination of antibiotics $600+$ silver nanoparticles. This result is in agreement with the findings of Krishna et al. ${ }^{48}$ 601 who mentioned increasing efficacies (percentage) of antibiotics like streptomycin and 602 ceftriaxone when used in combination with silver nanoparticles against Bacillus subtilis, 603 S. aureus, E. coli and Proteus vulgaris.

604 Shahnaz and Anima ${ }^{49}$, reported that in vitro antibacterial activity of silver nanoparticles 605 synthesized from Penicillium species were carried out in combination with the 606 Sparfloxacin and Ofloxacin antibiotics against clinically isolated pathogens 607 Staphylococcus aureus, Bacillus cereus, E. coli, and Proteus vulgaris. It was found that 608 the SNPs produced by Penicillium species enhanced the reaction rates of the antibiotics 609 in a synergistic mode on the clinically isolated pathogens

610 The Minimum Inhibitory Concentration (MIC) was defined as the lowest concentration of 611 the SNPs that can have antimicrobial effect on the test organisms. $10 \mathrm{mM}$ was used to 612 prepare the different concentrations of the SNPs for the MIC evaluation, different MICs 613 were recorded for the two (MDR) Salmonella spp. Balashanmugam et al. 30 also 614 reported the MIC of SNRs after testing on some pathogens with Escherichia coli and 615 Bacillus subtilis having the highest values.

\section{CONCLUSION}

617 The bioactive metabolites from the Bacillus spp. had antibacterial activity against the 618 selected MDR Salmonella spp. The bioactive metabolites were able to bio-reduced $619 \mathrm{AgNO}_{3}$ for SNPs biosynthesis. These biologically synthesized SNPs exhibited good 620 antibacterial activity and the combination of SNPs with some antibiotics equally 621 enhances the antibacterial potential of the antibiotics against the tested isolates. Thus, 622 these nanoparticles can be used as antibacterial agents alone or in combination with 
623 antibiotics to improve their antibacterial potential.

624

625 Disclosure of potential Conflict of Interest

626 The authors declared no conflict of interest.

627 


\section{Funding}

629 The research was funded by self.

\section{Conflict of Interest}

$631 \quad$ None

632

\section{REFERENCES}

1. Oveisi H, Rahighi S, Jiang X, Agawa Y, Beitollahi A, Soichi W, Yusuke Y. Improved inactivation effect of bacteria: Fabrication of mesoporous anatase films with fine Ag nanoparticles prepared by coaxial vacuum Arc deposition. Chem Lett., 2001; 40:420-422.

2. Thabit A, Crandon J, Nicolau D. Antimicrobial resistance: Impact on clinical and economic outcomes and the need for new antimicrobials. Exp Opin Pharmacother. 2015;16:159-177

642

3. Maisonneuve E, Gerdes K. Molecular mechanisms underlying bacterial persisters. Cell 2014;157:539-548.

4. Ferri M, Ranucci E, Romagnoli P, Giaccone V. Antimicrobial resistance: A global emerging threat to public health systems. Crit Rev Fd Sci Nutr. 2015; 2857-2876

5. Montville TJ, Matthews KR. Food microbiology: An introduction (2nd ed.). United States of America: ASM Press, Washington. 2008.

6. Rui CF, Wong WC, Chai LC, Nillian E, Ghazali FM, Cheah YK, Nakaguchi Y, Nishibuchi M, Radu S. (2011b) Simultaneous detection of Salmonella spp., Salmonella typhi and Salmonella typhimurium in sliced fruits using multiplex PCR. Fd Contr 22: 337-342 typhoid fever case, Pakistan," Emerg Infectious Dis 9(12):1621-1622, 
9. Schaffer B, Hohenester U, Trugler A, Hofer F (2009) High-resolution surface plasmon imaging of gold nanoparticles by energy-filtered transmission electron microscopy. Physical Rev 79:1-10.

10.Service ER. Foodborne Illness Cost Calculator: Salmonella. Washington, United States Department of Agriculture; 2009.

11. Morikawa M, Ito M, Imanaka T. Isolation of a new surfactin producer Bacillus pumilus $\mathrm{A}-1$, and cloning and nucleotide sequence of the regulator gene, psf-1. J Ferment Bioeng. 1992; 74 (5): 255-261.

12. Perez C, Suarez C, Castro GR. Production of antimicrobials by Bacillus subtilis MIR 15. J Biotechnol. 1992; 26: 331-336.

13. Perez C, Suarez C, Castro GR Antimicrobial activity determined in strains of Bacillus circulans cluster. Folia Microbiol. 1993; 38 (1): 25-28

14.Drablos F, Nicholson D, Ronning M. EXAFS study of zinc coordination in Bacitracin A. Biochim Biophys Acta, 1999;1431:433-442.

15. Milner JL, Raffel SJ, Lethbridge BJ, Handelsman J. Culture conditions that influence accumulation of zwittermicin a by Bacillus cereus UW85. Appl. Microbiol. Biotechnol. 1995; 43 (4), 685-691.

16. Steller S, Vollenbroich D, Leenders F, Stein T, Conrad B, Hofemeisterr J, Jaques $P$, Thonart $P$, Vater J., Structural and functional organization of the fengycin synthease multienzyme system from Bacillus subtilis b213 and A1/3. Chem. Biol. $1999 ; 6$ (1), 31-41.

Galvez A, Maqueda M, Cordovilla P, Martinez-Bueno M, Lebbadi M, Valdivia E. Characterization and biological activitiy against Naegleria fowleri of amonebicins produced by Bacillus licheniformis D-13. Antimicrob. Agents Chemother. 1994; 38 (6), 1314-1319. 
CL45. J Appl Bacteriol. 1995; 78(2):97-108. nanoparticles using bacterial exopolysaccharide and its antimicrobial activity 
against food and multi-drug resistant pathogens. Process Biochem. 2013; 48:1099-1106

690

691

692

693

694

695

696

697

698

699

700

701

702

703

704

705

706

707

708

709

710

711

712

20. Castellano JJ, Shafii SM, Ko F, Donate G, Wright TE, Mannari RJ, Payne WG, Smith DJ. Comparative evaluation of silver-containing antimicrobial dressings and drugs. Intern Wound J, 2007; 4: 14-22.

21. Kim JS, Kuk E, Yu KN, Kim J, Park SJ, Lee HJ, Kim SH, Park YK, Park YH, Hwang C, Kim Y, Lee Y, Jeong DH, Cho M. Antimicrobial effects of silver nanoparticles. Nanomed. Nanotechnol. Biol. Med. 2007; 3:95-101.

22. Morone JR, Elechiguerra JL, Camacho A, Holt K, Kouri JB, Ramirez JT. The bactericidal characterization of silver nanoparticles. Nanotechnol. 2005; 16 : 2340-2353.

23. Sondi I, Salopek-Sondi B. Silver nanoparticles as antimicrobial agent: a case study on E. coli as a model for Gram-negative bacteria. J. Colloid Interface Sci. 2004; 275:177-182.

24. Rai M, Yadav A, Gade A, Silver nanoparticles as a new generation of antimicrobials. Biotechnol. Adv. 2009; 27:76-83.

25. Lim HK, Asharani PV, Hande MP. Enhanced genotoxi- city of silver nanoparticles in DNA repair deficient mammalian cells. Front Genet. 2012; 3: 1-13.

26. Stevanovic MM, Skapin SD, Bracko I, Milenkovic M, Petkovic J, Filipic M. Poly(lactide-co-glycolide)/silver nanoparticles: Synthesis, character-ization, antimicrobial activity, cytotoxicity assessment and ROS-inducingpotential. Polymer, 2012; 53: 2818-28.

27. Karthik R, Nanasivayam S, Gnanendra KE, Reepika R. Synthesis of silver nanoparticles by $L$. acidophilus 01 strain and evaluation of its in vitro genomic DNA toxicity. Nano-micro Let. 2010; 2(3): 160-163.

28. Mandal D, Bolander ME, Mukhopadhyay D, Sarkar G, Mukherjee P. Appl Microbiol Biotechnol. 2006; 69:485

29. Singh D, Rathod V, Ninganagouda S, Herimath J, Kulkarni P. "Biosynthesis of silver nanoparticle by endophytic fungi Penicillium sp. isolated from Curcuma longa (turmeric) and its antibacterial activity against pathogenic gram negative 


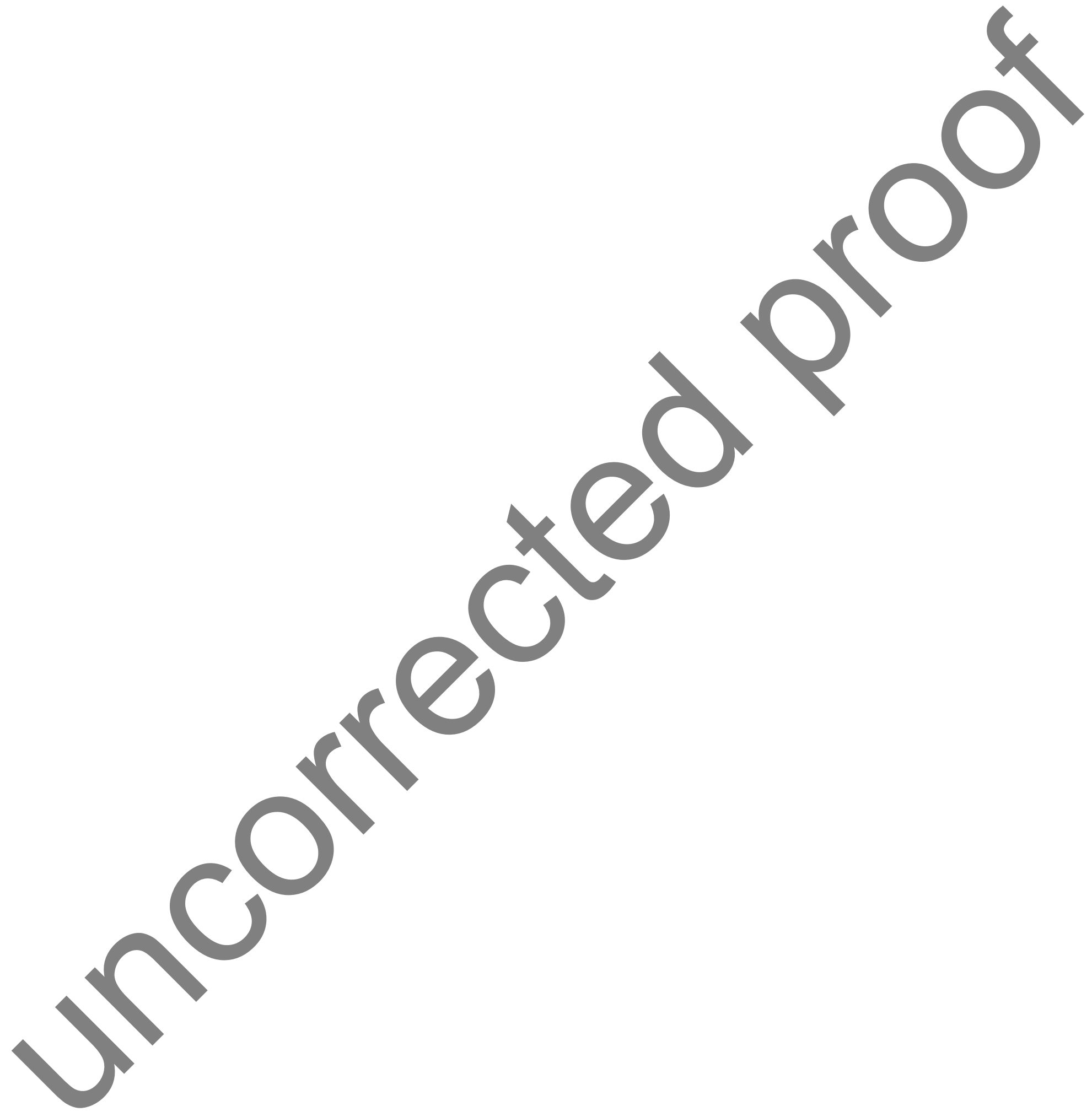


30. Balashanmugam P, Santhosh S, Giyaullah H, Balakumaran MD, Kalaichelvan PT. Mycosynthesis, characterization and antibacterial activity of silver nanoparticles from Microporus xanthopus: a macro Mushroom. International J Innova Res Sci, Engr Technol. 2013; 2(11): 1-9

31. Cappuccino JG, Sherman N A Laboratory Manual in General Microbiology, third ed., Benjamin Commius Publication Company Inc., California, 1996.

32. Riley MA, Wertz JE. Bacteriocins: evolution, ecology, and application. Annu Rev Microbiol. 2002; 56:117-137.

33. Kalishwaralal K, Deepak V, Ram Kumar Pandian S, Gurunathan S. Biosynthesis of gold nanocubes from Bacillus lichemiformis. Biores Technol. 2009; 100: 53565358.

34. Kanmani P, Lim ST. Synthesis and structural characterization of silver nanoparticles using bacterial exopolysaccharide and its antimicrobial activity against food and multidrug resistant pathogens. Process Biochem. 2013; 48: 1099-1106

734

735

736

35. El-Batal A, Amin M, Shehata M, HallotM. Synthesis of silver nanoparticles by Bacillus stearothermophilus using gamma radiation and their antimicrobial activity. World Appl Sci J. 2012; 22(1): 01-16

36. Valencia GA, Vercik LC, Ferrari R, Vercik A. Synthesis and characterization of silver nanoparticles using water-soluble starch and its antibacterial activity on Staphylococcus aureus. Starch/Stärke, 2013; 65: 1-7.

37. Schaffer B, Hohenester U, Trugler A, Hofer F (2009) High-resolution surface plasmon imaging of gold nanoparticles by energy-filtered transmission electron microscopy. Physical Rev 79:1-10.

38. Sadowski Z, Maliszewska IH, Grochowalska B, Polowczyk I, Koźlecki T. Synthesis of silver nanoparticles using microorganisms. Mater Sci. Poland, 2008; $26(2): 419-424$.

39. Gardea-Torresday LJ, Gomez E, Peratta-Videa RJ, Persons GJ, Troiani H, JoseYacaman M. Alfalfa sprouts: A natural source for synthesis of silver nanoparticles. Langmuir, 2003; 19: 1357-1361. 
40. Vithiya K, Kumar R, Sen S. Bacillus spp. Mediated extracellular synthesis of silver nanoparticles. Inter J Pharm Pharmaceut Sci. 2014; 6:3

41. Guzman M, Dille J, Godet S. Synthesis and antibacterial activity of silver nanoparticles against Gram-positive and Gram-negative bacteria. Nanomed Nanotechnol Biol Med. 2012; 8: 35-45.

42. Sharma VK, Yngard RA, Lin Y. Silver nanoparticles: Green synthesis and their antimicrobial activities. Adv Colloid Interf Sci. 2009; 145: 83-96.

43. Dhanalakshmi T, Rajendran S. Synthesis of silver nanoparticles using Tridax procumbens and its antimicrobial activity. Arch Appl Sci Res. 2012; 4(3): 12891293.

44. Natarajan K, Selvaraj S. Green synthesis of silver nanoparticles using Bacillus subtilis 1A751 and its antimicrobial activity. Res J Nanosci Nanotechnol. 2011; 10: 1-8

45. Muhammad Amin, Anwar F, Janjua MRSA, Iqbal MA, Rashid U. Green Synthesis of Silver Nanoparticles through Reduction with Solanum xanthocarpum L. Berry Extract: Characterization, Antimicrobial and Urease Inhibitory Activities against Helicobacter pylori. Intern. J Molecu Sci. 2012; 13: 9923-9941.

46. Goldie O, SunilP, Ashmí M, Golap K, Madhuri S. Facile biosynthesis of gold nanoparticles exploiting optimum $\mathrm{pH}$ and temperature of fresh water algae Chlorella pyrenoidusa. Adv Appl Sci. 2012; Res 3 (3):1405-1412 47. Annadurai G, Vanaja M. Coleus aromaticus leaf extract mediated synthesis of silver nanoparticles and its bactericidal activity. Appl Nanosci, 2013; 3(1):217223. 48. Krishna G, Kumar SS, Pranitha V, Alha M, Charaya S. Biogenic Synthesis of Silver Nanoparticles and their Synergistic Effect with Antibiotics: A Study against Salmonella Sp. International J Pharmaceu Sci. 2015; 7(10): 1-5. 
Pharm Tech Res. 2014; 6(3):1049-1053

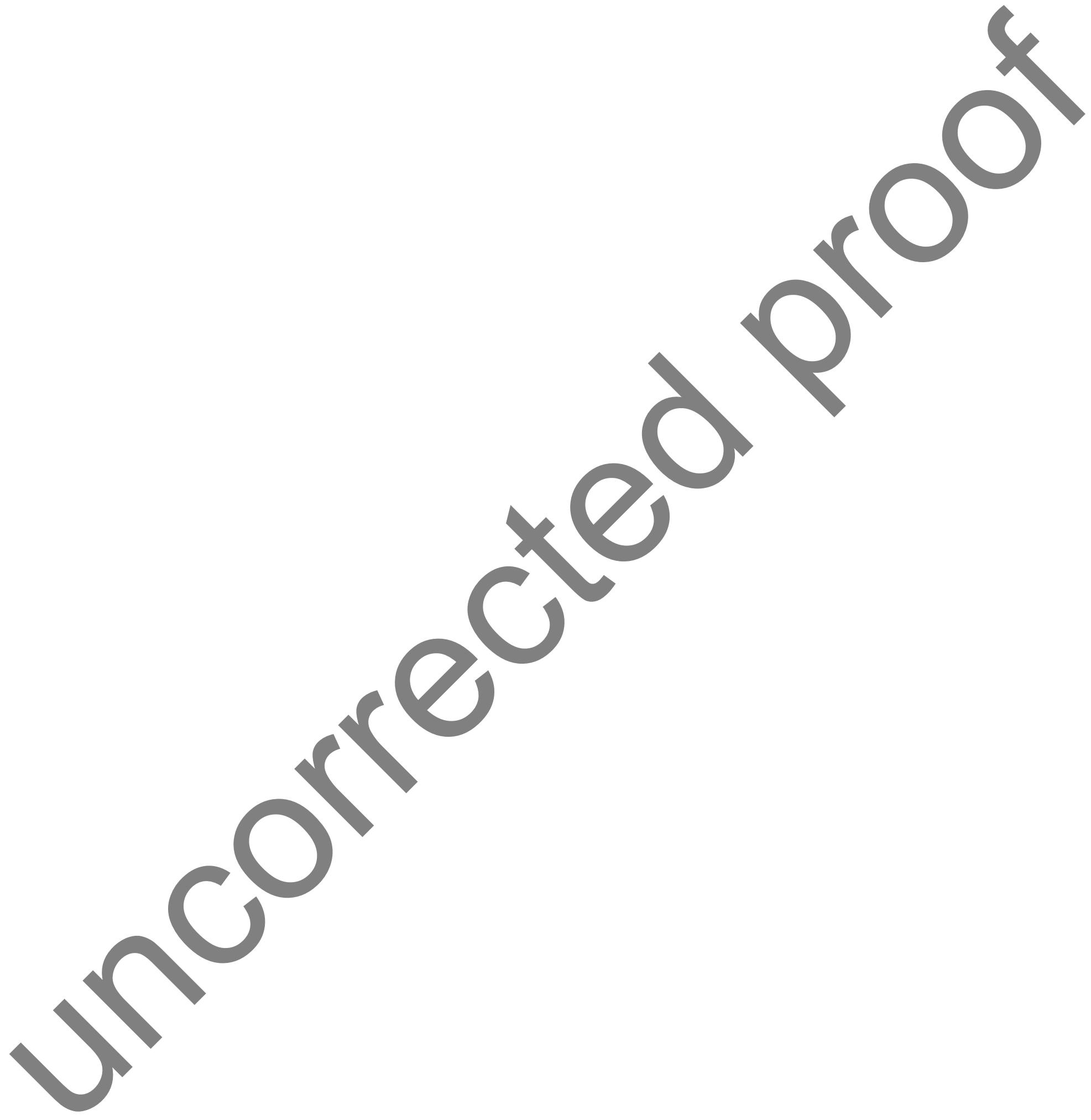

